\title{
Sensitivity analysis of the potential impact of discrepancies in stratosphere-troposphere exchange on inferred sources and sinks of $\mathrm{CO}_{2}$
}

\author{
F. Deng ${ }^{1}$, D. B. A. Jones ${ }^{1,2}$, T. W. Walker ${ }^{1}$, M. Keller ${ }^{1}$, K. W. Bowman ${ }^{3,2}$, D. K. Henze ${ }^{4}$, R. Nassar ${ }^{5}$, E. A. Kort ${ }^{6}$, \\ S. C. Wofsy ${ }^{7}$, K. A. Walker ${ }^{1}$, A. E. Bourassa ${ }^{8}$, and D. A. Degenstein ${ }^{8}$ \\ ${ }^{1}$ Department of Physics, University of Toronto, Toronto, ON, Canada \\ ${ }^{2}$ Joint Institute for Regional Earth System Science and Engineering, University of California, Los Angeles, CA, USA \\ ${ }^{3}$ Jet Propulsion Laboratory, California Institute of Technology, Pasadena, CA, USA \\ ${ }^{4}$ Department of Mechanical Engineering, University of Colorado, Boulder, CO, USA \\ ${ }^{5}$ Climate Research Division, Environment Canada, Toronto, ON, Canada \\ ${ }^{6}$ Department of Atmospheric, Oceanic and Space Sciences, University of Michigan, Ann Arbor, MI, USA \\ ${ }^{7}$ Harvard University, Cambridge, MA, USA \\ ${ }^{8}$ Institute of Space and Atmospheric Studies, University of Saskatchewan, Saskatoon, Canada
}

Correspondence to: F. Deng (dengf@atmosp.physics.utoronto.ca)

Received: 25 February 2015 - Published in Atmos. Chem. Phys. Discuss.: 14 April 2015

Revised: 30 September 2015 - Accepted: 12 October 2015 - Published: 23 October 2015

\begin{abstract}
The upper troposphere and lower stratosphere (UTLS) represents a transition region between the more dynamically active troposphere and more stably stratified stratosphere. The region is characterized by strong gradients in the distribution of long-lived tracers, whose representation in models is sensitive to discrepancies in transport. We evaluate the GEOS-Chem model in the UTLS using carbon dioxide $\left(\mathrm{CO}_{2}\right)$ and ozone $\left(\mathrm{O}_{3}\right)$ observations from the HIAPER (The High-Performance Instrumented Airborne Platform for Environmental Research) Pole-to-Pole Observations (HIPPO) campaign in March 2010. GEOS-Chem $\mathrm{CO}_{2} / \mathrm{O}_{3}$ correlation suggests that there is a discrepancy in mixing across the tropopause in the model, which results in an overestimate of $\mathrm{CO}_{2}$ and an underestimate of $\mathrm{O}_{3}$ in the Arctic lower stratosphere. We assimilate stratospheric $\mathrm{O}_{3}$ data from the Optical Spectrograph and InfraRed Imager System (OSIRIS) and use the assimilated $\mathrm{O}_{3}$ fields together with the HIPPO $\mathrm{CO}_{2} / \mathrm{O}_{3}$ correlations to obtain an adjustment to the modeled $\mathrm{CO}_{2}$ profile in the Arctic UTLS (primarily between the 320 and $360 \mathrm{~K}$ isentropic surfaces). The HIPPOderived adjustment corresponds to a sink of $0.60 \mathrm{PgC}$ for March-August 2010 in the Arctic. Imposing this adjustment results in a reduction in the $\mathrm{CO}_{2}$ sinks inferred from GOSAT observations for temperate North America, Europe, and trop-
\end{abstract}

ical Asia of 19, 13, and $49 \%$, respectively. Conversely, the inversion increased the source of $\mathrm{CO}_{2}$ from tropical South America by $23 \%$. We find that the model also underestimates $\mathrm{CO}_{2}$ in the upper tropical and subtropical troposphere. Correcting for the underestimate in the model relative to HIPPO in the tropical upper troposphere leads to a reduction in the source from tropical South America by $77 \%$, and produces an estimated sink for tropical Asia that is only $19 \%$ larger than the standard inversion (without the imposed source and sink). Globally, the inversion with the Arctic and tropical adjustment produces a sink of $-6.64 \mathrm{Pg} \mathrm{C}$, which is consistent with the estimate of $-6.65 \mathrm{PgC}$ in the standard inversion. However, the standard inversion produces a stronger northern land sink by $0.98 \mathrm{PgC}$ to account for the $\mathrm{CO}_{2}$ overestimate in the high-latitude UTLS, suggesting that this UTLS discrepancy can impact the latitudinal distribution of the inferred sources and sinks. We find that doubling the model resolution from $4^{\circ} \times 5^{\circ}$ to $2^{\circ} \times 2.5^{\circ}$ enhances the $\mathrm{CO}_{2}$ vertical gradient in the high-latitude UTLS, and reduces the overestimate in $\mathrm{CO}_{2}$ in the extratropical lower stratosphere. Our results illustrate that discrepancies in the $\mathrm{CO}_{2}$ distribution in the UTLS can affect $\mathrm{CO}_{2}$ flux inversions and suggest the need for more careful evaluation of model errors in the UTLS. 


\section{Introduction}

The Greenhouse Gases Observing Satellite (GOSAT), the first satellite launched specifically to monitor atmospheric carbon dioxide $\left(\mathrm{CO}_{2}\right)$ from space, has been providing greater observational coverage of atmospheric $\mathrm{CO}_{2}$ than is possible from existing surface observation networks. The expectation has been that these data would offer greater constraints on atmospheric $\mathrm{CO}_{2}$, and hence improve estimates of regional sources and sinks of $\mathrm{CO}_{2}$. However, although global flux estimates from various inversion analyses constrained by GOSAT data have been found to be consistent across the different inversion analyses, and in good agreement with optimized fluxes based on flask $\mathrm{CO}_{2}$ measurements, regional flux estimates have not been robust (e.g. Maksyutov et al., 2013; Basu et al., 2013; Chevallier et al., 2014; Deng et al., 2014). Deng et al. (2014), for example, found that flux estimates for temperate North America and tropical South America were particularly sensitive to the treatment of the regional bias in the GOSAT data. Chevallier et al. (2014) showed that model errors are another source of discrepancy in the regional fluxes inferred from GOSAT $\mathrm{CO}_{2}$ data.

Inversion analyses using satellite observations have also produced large differences in the flux estimates from some regions, such as Europe and northern Africa, relative to those inferred from the surface-observing network. Reuter et al. (2014) noted that the satellite-derived flux estimates for Europe are more than a factor of two larger than those obtained from in situ surface data. It is difficult to determine whether the differences between the fluxes inferred from the satellite data and those based on the surface data reflect actual additional information provided by the satellite data or discrepancies in the free troposphere in the models, to which the surface data would be much less sensitive.

Observations from instruments such as GOSAT and the Orbiting Carbon Observatory 2 (OCO-2) are vertically integrated column abundances of $\mathrm{CO}_{2}$ (referred to as $\mathrm{XCO}_{2}$ ), and it is expected that inversion analyses using these data will be less sensitive to vertical transport errors, such as mixing in the planetary boundary layer (PBL), than those using in situ surface data. However, Lauvaux and Davis (2014) found that vertical transport errors are still an issue for inversion analyses using column data. Stephens et al. (2007) showed that models that do not correctly capture the vertical transport of $\mathrm{CO}_{2}$ between the PBL and the free troposphere, and, consequently, overestimate the vertical gradient in $\mathrm{CO}_{2}$, and tend to suggest a stronger extra-tropical land sink of $\mathrm{CO}_{2}$. It is unclear how sensitive the $\mathrm{XCO}_{2}$-based inversions are to model errors in transport in the free troposphere. We examine here the potential impact of discrepancies in $\mathrm{CO}_{2}$ in the upper troposphere and lower stratosphere (UTLS) on the regional flux estimates inferred from GOSAT $\mathrm{XCO}_{2}$ data. We focus on the UTLS because this is a region that has been neglected as an important source of error in $\mathrm{CO}_{2}$ flux inversions, even though it is characterized by strong vertical gradients in the distribu- tion of long-lived tracers and by complex transport processes that occur on a range of spatial and temporal scales that can be challenging for models to reliably capture.

In the extratropics, the latitudinal distribution of $\mathrm{CO}_{2}$ is strongly influenced by quasi-adiabatic transport that tends to align the $\mathrm{CO}_{2}$ distribution along the isentropes (although diabatic effects result in cross-isentropic transport) (Miyazaki et al., 2008). This can be seen in Fig. 1, which shows the zonal mean $\mathrm{CO}_{2}$ distribution on 1 April 2010 estimated using the GEOS-Chem model. Also shown are the isentropic surfaces in the model. In the tropics, convective transport provides a means for fast transport of $\mathrm{CO}_{2}$ from the lower to the upper troposphere. In the extratropics, isentropic transport plays an important role in the export of air from the PBL to the free troposphere. Parazoo et al. (2012) showed that not properly capturing this isentropic transport of $\mathrm{CO}_{2}$ could impact $\mathrm{CO}_{2}$ flux inversions. They conducted an observing system simulation experiment (OSSE) and found that data gaps in satellite measurements due to cloud cover, which is associated with poleward moist transport at mid-latitudes, could produce large biases in regional flux estimates. For example, in their perfect model OSSE, the sampling bias due to the data gaps resulted in a bias of $0.43 \mathrm{Pg} \mathrm{C} \mathrm{yr}^{-1}$ for the European flux estimates. Here we focus mainly on transport in the extratropical UTLS, where mixing along isentropic surfaces, such as the 320 and the $340 \mathrm{~K}$ surfaces, enables rapid exchange of $\mathrm{CO}_{2}$ between the high-latitude UTLS and the subtropical and mid-latitude middle and upper troposphere. Miyazaki et al. (2008) showed that in winter and spring, transport by large-scale eddies has a positive tendency on $\mathrm{CO}_{2}$ in the high-latitude UTLS, transporting air with high $\mathrm{CO}_{2}$ from the lower troposphere at lower latitudes. In contrast, transport by the mean meridional circulation has a negative tendency on $\mathrm{CO}_{2}$ in the high-latitude UTLS, due to the transport of low $\mathrm{CO}_{2}$ air from the tropical upper troposphere and down from the high-latitude stratosphere. Accurately reproducing the observed $\mathrm{CO}_{2}$ distribution in the UTLS requires models to reliably capture the compensating effects of these transport processes. The $\mathrm{CO}_{2}$ distribution will also be influenced by discrepancies in the numerical schemes and in the parameterizations of subgrid-scale processes not explicitly represented in the models.

We use observations of $\mathrm{CO}_{2}$ and ozone $\left(\mathrm{O}_{3}\right)$ from the HIAPER Pole-to-Pole Observations (HIPPO) campaign to evaluate the GEOS-Chem $\mathrm{CO}_{2}$ simulation in the high-latitude UTLS. The GEOS-Chem model has been widely used as a tropospheric chemistry transport model (CTM), but it is driven by assimilated meteorological fields from the Global Modeling and Assimilation Office (GMAO) that extend from the surface to $0.01 \mathrm{hPa}$, providing a full description of the circulation in the stratosphere. The model simulates a source of ozone from the stratosphere to the troposphere of about $500 \mathrm{Tg} \mathrm{O}_{3} \mathrm{yr}^{-1}$, which is consistent with the multi-model mean of $550 \mathrm{Tg} \mathrm{O}_{3} \mathrm{yr}^{-1}$ from Stevenson et al. (2006). However, although the model has been successfully used for stud- 

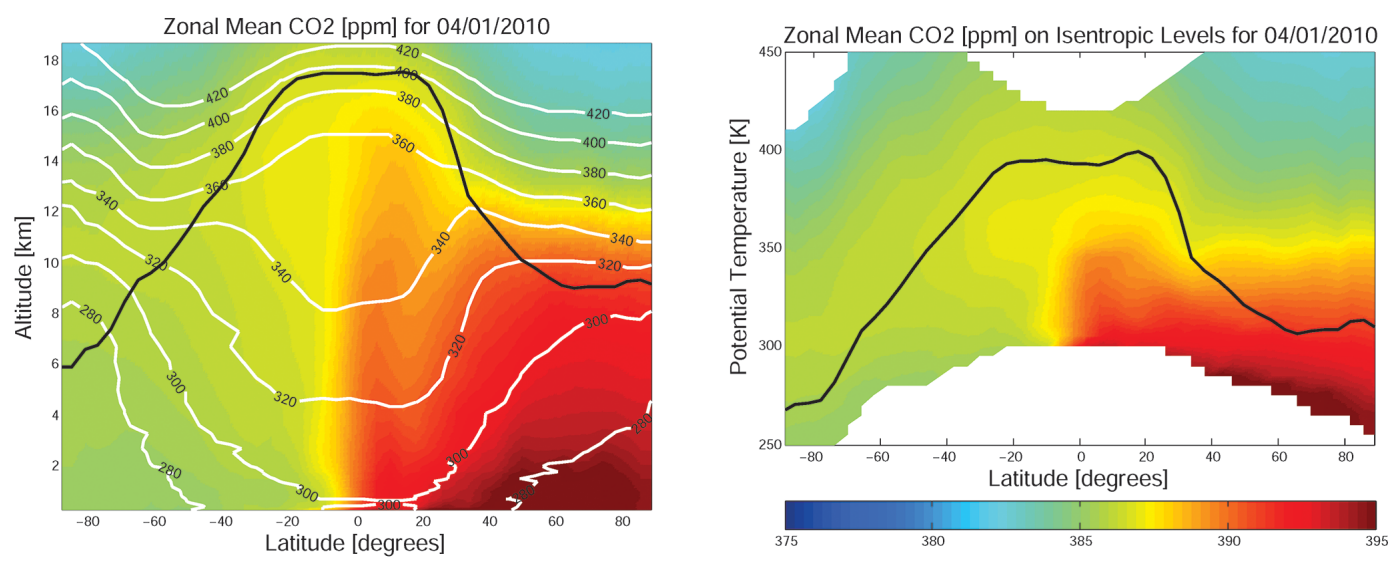

Figure 1. Zonal mean $\mathrm{CO}_{2}$ from GEOS-Chem on 1 April 2010, as a function of latitude and altitude (left) and latitude and potential temperature (right). In the latitude/altitude plot (left), the white lines indicate the zonal mean potential temperature in Kelvins (K). The thick black line in both plots denotes the location of the tropopause in the model.

ies of tropospheric chemistry and transport, we note the $\mathrm{CO}_{2}$ flux inversions are particularly sensitive to model errors. As discussed below, we find that the model overestimates $\mathrm{CO}_{2}$ relative to the HIPPO data in the high-latitude UTLS. We then use the HIPPO $\mathrm{CO}_{2} / \mathrm{O}_{3}$ correlations to impose an adjustment to the modeled $\mathrm{CO}_{2}$ in the high-latitude UTLS and conduct a series of inversion analyses of the GOSAT data, using the GEOS-Chem 4-dimensional variational (4D-var) data assimilation system, to quantify the potential impact of the UTLS adjustment in $\mathrm{CO}_{2}$ on regional flux estimates of $\mathrm{CO}_{2}$.

We begin in Sect. 2 with a brief discussion of the data and the methods. We use the same GOSAT data and 4D-var inversion approach as in Deng et al. (2014). In Sect. 3, we present our results, starting with a discussion of the use of the HIPPO $\mathrm{CO}_{2} / \mathrm{O}_{3}$ correlations to evaluate the model in the UTLS, followed by results of the 4D-var inversion analyses. Finally, we conclude with a discussion of the implications of our results in Sect. 4.

\section{Data and methods}

\subsection{Data sets}

We use here the NASA Atmospheric $\mathrm{CO}_{2}$ Observations from Space (ACOS) GOSAT $\mathrm{CO}_{2}$ data product (version b2.10) (O'Dell et al., 2012), spanning July 2009 to December 2010. The ACOS retrievals employ an optimal estimation approach to infer profile abundances of $\mathrm{CO}_{2}$ from the measurements of reflected shortwave infrared (SWIR) solar radiation made by the Thermal and Near-infrared Sensor for carbon Observation Fourier Transform Spectrometer (TANSO-FTS) onboard the GOSAT satellite. The retrieved $\mathrm{CO}_{2}$ is the total column dry-air mole fraction $\left(\mathrm{XCO}_{2}\right)$; consequently, when the data were assimilated into the model, the modeled fields are converted to $\mathrm{XCO}_{2}$ using the reported GOSAT a priori profile, column averaging kernel, and pressure weighting function. The GOSAT data used here are the same as those labeled "RUN_C" in Deng et al. (2014). We use only the "High gain" (H-gain) data, which excludes data over bright surfaces, such as deserts. We also neglect glint observations, which provide coverage over oceans, since the biases in the glint data are not as well-characterized in version b2.10 of the ACOS product. For additional details of the data set we refer the reader to Deng et al. (2014).

To evaluate the model simulation, we use data from the HIPPO aircraft campaign from March-April 2010 (campaign 3). HIPPO-3 sampled the atmosphere across the Pacific Ocean, from near the North Pole to the coastal region of Antarctica, and from the surface to $14 \mathrm{~km}$ (Wofsy et al., 2012). The altitudes of the flights were mostly below $9 \mathrm{~km}$, but extended up toward $14 \mathrm{~km}$ typically at least at the beginning and end of every flight. We focus here on data from the polar flights on 26-27 March 2010, when there were two profiles that extended up to about $14 \mathrm{~km}$ in the Arctic. The data used here are from the $10 \mathrm{~s}$ averaged data set. The $\mathrm{CO}_{2}$ data are from two (harmonized) sensors: the $\mathrm{CO}_{2}$ Quantum Cascade Laser Spectrometer (CO2-QCLS) and the $\mathrm{CO}_{2}$ Observations of the Middle Stratosphere instrument (CO2OMS). The $\mathrm{O}_{3}$ measurements were made by an ultraviolet (UV) ozone photometer (Wofsy et al., 2011).

We assimilate $\mathrm{O}_{3}$ data from the Optical Spectrograph and InfraRed Imager System (OSIRIS), which is a Canadian instrument on the Odin satellite. It was launched in February 2001 into a $600 \mathrm{~km}$ circular, Sun-synchronous, nearterminator orbit with an inclination of $97.8^{\circ}$ (Llewellyn et al., 2004). OSIRIS consists of a limb-viewing ultraviolet (UV)visible imaging spectrograph that measures scattered sunlight between $280-820 \mathrm{~nm}$, and a three-channel infrared imager measuring atmospheric airglow emissions near 1.27 and $1.53 \mu \mathrm{m}$. Vertical profiles of $\mathrm{O}_{3}$ are retrieved from OSIRIS measurements using a multiplicative algebraic reconstruction technique (Degenstein et al., 2009), with a vertical resolu- 
tion of about $2 \mathrm{~km}$ from the upper troposphere to $65 \mathrm{~km}$. We use version 5.07 of the $\mathrm{O}_{3}$ data. As a result of the orbit of the satellite, observational coverage is limited to the summer hemisphere, with near-global coverage during the equinoxes and year-round coverage in the tropics. The mean relative difference between the retrieved $\mathrm{O}_{3}$ profiles and those from the Stratospheric Aerosol and Gas Experiment (SAGE) II is less than $5 \%$ between $13.5-54.5 \mathrm{~km}$, and less than $3 \%$ between 24.5-53.5 km (Adams et al., 2013). The precision is better than $5 \%$ between $25-50 \mathrm{~km}$, but degrades at lower altitudes, increasing to $5-15 \%$ between $10-20 \mathrm{~km}$ in the extratropics (Bourassa et al., 2012).

The assimilation of the OSIRIS data is evaluated using observations from the Atmospheric Chemistry Experiment Fourier Transform Spectrometer (ACE-FTS), which is a high-resolution Fourier transform spectrometer (Bernath et al., 2005) on the Atmospheric Chemistry Experiment (ACE) satellite (also known as SCISAT). SCISAT was launched in August 2003, into a low Earth orbit at an altitude of $650 \mathrm{~km}$ with an inclination of $74^{\circ}$. ACE-FTS measures infrared radiation between $2.2-13.3 \mu \mathrm{m}\left(750-4400 \mathrm{~cm}^{-1}\right)$ with a resolution of $0.02 \mathrm{~cm}^{-1}$ by solar occultation. The retrieval products (Boone et al., 2005) include vertical profiles of numerous trace gases ranging from the mid-troposphere up to $150 \mathrm{~km}$ depending on the gas. We use version 2.2 of the ACE-FTS ozone data. Hegglin et al. (2008) found that the version 2.2 ACE-FTS profiles have an effective vertical resolution of $1 \mathrm{~km}$ in the UTLS. Validation of the ACE-FTS $\mathrm{O}_{3}$ data suggested that the relative mean difference between ACE-FTS $\mathrm{O}_{3}$ data and independent measurements is less than $8 \%$ between $16-44 \mathrm{~km}$. Hegglin et al. (2008) evaluated the data in the UTLS and reported mean differences relative to aircraft and ozonesonde data of about $8 \%$ in the lower stratosphere and a high bias of $18 \%$ in the upper troposphere. We restrict our use of the ACE-FTS data to the lower stratosphere.

\subsection{The GEOS-Chem model and assimilation approach}

We use the GEOS-Chem (http://geos-chem.org) 4D-var data assimilation system (Henze et al., 2007) to infer regional $\mathrm{CO}_{2}$ flux estimates. The model is driven by assimilated meteorology from the Goddard Earth Observing System (GEOS5) of the NASA GMAO. The native horizontal resolution is $0.5^{\circ} \times 0.67^{\circ}$ with 72 vertical levels from the surface to 0.01 $\mathrm{hPa}$, but we degrade the resolution to $4^{\circ} \times 5^{\circ}$ and 47 vertical layers (with the reduction in vertical resolution in the middle and upper stratosphere). The GEOS-Chem $\mathrm{CO}_{2}$ simulation is described and evaluated in Nassar et al. (2010). Details of the model configuration and setup of the 4D-Var system are described in Deng et al. (2014). Here we will provide only a brief description of the modeling setup.
In the 4D-Var approach, we iteratively minimize a cost function $J$ as a function of $\mathrm{CO}_{2}$ fluxes $(\boldsymbol{x})$,

$$
\begin{aligned}
J(x) & =\frac{1}{2}\left(H(x)-y^{0}\right)^{T} \mathbf{S}_{\mathrm{o}}^{-1}\left(H(x)-\boldsymbol{y}^{\mathrm{o}}\right) \\
& +\frac{1}{2}\left(\boldsymbol{x}-\boldsymbol{x}_{\mathrm{a}}\right)^{T} \mathbf{S}_{\mathrm{a}}^{-1}\left(\boldsymbol{x}-\boldsymbol{x}_{\mathrm{a}}\right),
\end{aligned}
$$

where $\boldsymbol{y}^{\mathrm{o}}$ is a vector of GOSAT $\mathrm{XCO}_{2}$ observations and $\mathbf{S}_{\mathrm{o}}$ and $\mathbf{S}_{\mathrm{a}}$ are the observational and a priori error covariance matrices, respectively. $H$ is the forward atmospheric model $(\boldsymbol{y}=H(\boldsymbol{x}))$, which includes the GEOS-Chem simulation of the $\mathrm{CO}_{2}$ distribution and the transformation of the modeled $\mathrm{CO}_{2}$ profile to $\mathrm{XCO}_{2}$ using the GOSAT averaging kernels and a priori profiles. We solve for monthly mean fluxes of $\mathrm{CO}_{2}$ using GOSAT observations from MarchAugust 2010. Following Deng et al. (2014), the reported observational $\mathrm{XCO}_{2}$ uncertainties are uniformly inflated by a factor of 1.175 when the data are ingested into the GEOSChem assimilation system.

As described in Deng et al. (2014), the prior $\mathrm{CO}_{2}$ fluxes $\left(\boldsymbol{x}_{\mathrm{a}}\right)$ imposed in the model are: (i) monthly national fossil fuel and cement manufacture $\mathrm{CO}_{2}$ emissions from the Carbon Dioxide Information Analysis Center (CDIAC) (Andres et al., 2011); (ii) monthly shipping emissions of $\mathrm{CO}_{2}$ from the International Comprehensive Ocean-Atmosphere Data Set (ICOADS) (Corbett and Koehler, 2003; Corbett, 2004; Endresen et al., 2004, 2007); (iii) 3-D aviation $\mathrm{CO}_{2}$ emissions (Kim et al., 2007; Wilkerson et al., 2010; Friedl, 1997); (iv) monthly mean biomass burning $\mathrm{CO}_{2}$ emissions from the Global Fire Emissions Database version 3 (GFEDv3) (van der Werf et al., 2010); (v) biofuel (heating/cooking) $\mathrm{CO}_{2}$ emissions estimated by Yevich and Logan (2003); (vi) the flux of $\mathrm{CO}_{2}$ across the air-water interface based on the climatology of monthly ocean-atmosphere $\mathrm{CO}_{2}$ flux by Takahashi et al. (2009); and (vii) 3-hourly terrestrial ecosystem exchange produced by the Boreal Ecosystem Productivity Simulator (BEPS) (Chen et al., 1999), which was driven by NCEP reanalysis data (Kalnay et al., 1996) and remotely sensed leaf area index (LAI) (Deng et al., 2006). The annual terrestrial ecosystem exchange imposed in each grid box is neutral (Deng and Chen, 2011). The assumed prior errors $(1 \sigma)$, specified for each grid box and each month, are $16 \%$ for the fossil fuel emissions, $38 \%$ for the biomass burning emissions, and $44 \%$ for the ocean flux. For gross primary production (GPP) and total ecosystem respiration (TER), we assumed an uncertainty of $22 \%$ in each 3-hour time step and in each model grid box.

The assimilation of the OSIRIS $\mathrm{O}_{3}$ data into GEOS-Chem uses the same 4D-var approach as described in Eq. (1). However, instead of optimizing a model parameter, such as the surface fluxes of $\mathrm{CO}_{2}$, we optimize the $\mathrm{O}_{3}$ distribution at the beginning of the assimilation period (the initial conditions) so that the model better matches the OSIRIS data over the assimilation period. For the results presented here, the assimilation period extended from 20 March to 2 April 2010. The 
$\mathrm{O}_{3}$ distribution in GEOS-Chem is simulated with a detailed description of $\mathrm{O}_{3}-\mathrm{NOx}$-hydrocarbon chemistry in the troposphere, but the version of the model employed here uses a linearized version of the chemistry in the stratosphere, based on the Linoz scheme from McLinden et al. (2000). As mentioned above, with the Linoz scheme, the model simulates a source of tropospheric ozone of about $500 \mathrm{Tg} \mathrm{O}_{3} \mathrm{yr}^{-1}$, which is close to the multi-model mean of $550 \mathrm{Tg} \mathrm{O}_{3} \mathrm{yr}^{-1}$ from Stevenson et al. (2006). We note that degrading the vertical resolution in the stratosphere (from 72 to 47 levels) does not impact the stratospheric source of ozone into the troposphere, suggesting that stratosphere-troposphere exchange (STE) is not influenced by the reduction in levels in the middle and upper stratosphere. Additional details of the configuration of the $\mathrm{O}_{3}$ simulation in the version of GEOS-Chem used here are described in Zhang et al. (2011). The use of the GEOSChem 4D-var system for assimilation of ozone observations is described in Singh et al. (2011).

\section{Results and discussion}

\section{$3.1 \mathrm{CO}_{2} / \mathrm{O}_{3}$ correlations in the Arctic}

Deng et al. (2014) compared the a posteriori $\mathrm{CO}_{2}$ fields from their inversion analysis of the GOSAT data to HIPPO-3 data in the lower troposphere (between $1-5 \mathrm{~km}$ ) and found that the mean differences between the model and the data were small, less than $0.20 \mathrm{ppm}$. In Fig. 2, we compare the a posteriori $\mathrm{CO}_{2}$ fields (defined as our standard inversion here) with the HIPPO-3 data in the upper troposphere (above $5 \mathrm{~km}$ ). The linear correlation between the HIPPO-3 observations and the modeled $\mathrm{CO}_{2}$ is high, $R^{2}=0.7708$, but there is a large bias at high latitudes in the Northern Hemisphere, where the observed $\mathrm{CO}_{2}$ mixing ratio values are much lower than the modeled $\mathrm{CO}_{2}$. The HIPPO data are $10 \mathrm{~s}$ averages, and we are aware that at a temporal resolution of $10 \mathrm{~s}$, the HIPPO data will reflect $\mathrm{CO}_{2}$ on spatial scales that are much smaller than the model resolution. Consequently, representativeness errors associated with the coarse model grid and temporal resolution will contribute to the differences between the model and the data. Xiong et al. (2013) reported the occurrence of a strong stratospheric intrusion over North America on 27 March 2010, which was captured by the HIPPO data. They reported significantly reduced $\mathrm{CH}_{4}$ values, reflecting stratospheric air that was transported down as low as $550 \mathrm{hPa}$, which would be consistent with the low $\mathrm{CO}_{2}$ values of 385 ppm measured by HIPPO (in Fig. 2). Because of the coarse horizontal resolution of the model simulation, it is possible that the model underestimates the stratospheric intrusion (e.g., Lin et al., 2012).

The influx of stratospheric air will be associated with low $\mathrm{CO}_{2}$ and high $\mathrm{O}_{3}$; therefore, we examined the $\mathrm{CO}_{2} / \mathrm{O}_{3}$ correlations in the HIPPO data and in the model. Tracer-tracer correlations have been used extensively to study transport

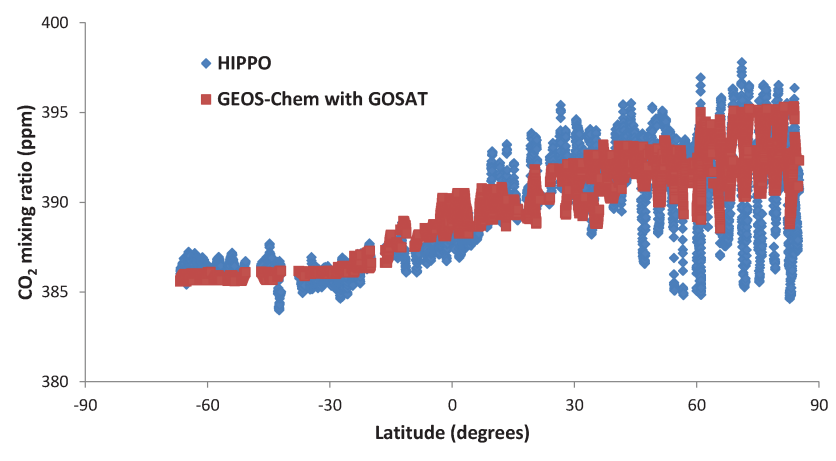

Figure 2. Comparison of modeled a posteriori $\mathrm{CO}_{2}$ mixing ratios in the upper troposphere from our GOSAT inversion analysis (in red) with HIPPO observations (in blue) between $70^{\circ} \mathrm{S}$ to $84^{\circ} \mathrm{N}$ and above $5000 \mathrm{~m}$ in altitude. These a posteriori $\mathrm{CO}_{2}$ fields are from the inversion denoted as our standard inversion.

and mixing in the stratosphere (e.g., Plumb and Ko, 1992; Waugh et al., 1997; Hoor et al., 2002; Sankey and Shepherd, 2003; Pan et al., 2004). The correlations, shown in Fig. 3, indicate a clear separation of tropospheric air (with low ozone and high $\mathrm{CO}_{2}$ ) and stratospheric air (with high ozone and low $\mathrm{CO}_{2}$ ), with a mixing region in between, with intermediate $\mathrm{CO}_{2}$ and $\mathrm{O}_{3}$ values that reflect the mixing between the tropospheric and stratospheric air masses. Shown also are linear fits to the HIPPO data in the stratospheric and mixing regions. Assuming an ozone threshold of $100 \mathrm{ppb}$ as the transition from tropospheric air to stratospheric air (e.g., Pan et al., 2004), the intercept of the stratospheric branch with the $100 \mathrm{ppb}$ ozone threshold suggests a tropopause $\mathrm{CO}_{2}$ level of about $387 \mathrm{ppm}$, in the absence of mixing. The modeled correlation agrees well with the data in the tropospheric and stratospheric branches, but the modeled values are displaced to higher $\mathrm{CO}_{2}$ compared to the aircraft data in the mixing region, suggesting excessive mixing in the model (e.g., Hoor et al., 2002; Pan et al., 2004). We believe that the two clear mixing lines in Fig. 3 reflect the effects of the intrusion reported by Xiong et al. (2013), which the model does not capture. The mixing feature starting at $\mathrm{CO}_{2}$ and $\mathrm{O}_{3}$ abundances of $385 \mathrm{ppm}$ and $400 \mathrm{ppb}$, respectively, corresponds to stratospheric air extending down to $7-8 \mathrm{~km}$, while the feature starting at $\mathrm{CO}_{2}$ and $\mathrm{O}_{3}$ abundances of $386 \mathrm{ppm}$ and $300 \mathrm{ppb}$, respectively, extends down to $5-7 \mathrm{~km}$. Although the model does not capture these features, the correlations suggest that the mean state of the model in the UTLS is characterized by stronger mixing than suggested by the observations.

Examination of the $\mathrm{CO}$ and $\mathrm{O}_{3}$ correlations reveals a similar discrepancy, with the modeled $\mathrm{CO}$ and $\mathrm{O}_{3}$ correlation shifted relative to the HIPPO data, as shown for $\mathrm{CO}_{2}$ and $\mathrm{O}_{3}$ in Fig. 3. The HIPPO $\mathrm{CO} / \mathrm{O}_{3}$ correlations also show the influence of the enhanced STE at $\mathrm{O}_{3}$ values less than $400 \mathrm{ppb}$, which is not captured by the model. We also examined the $\mathrm{CO} / \mathrm{O}_{3}$ and $\mathrm{CO}_{2} / \mathrm{O}_{3}$ correlations in HIPPO- 1 in January 2009 and found similar discrepancies between the model and the 


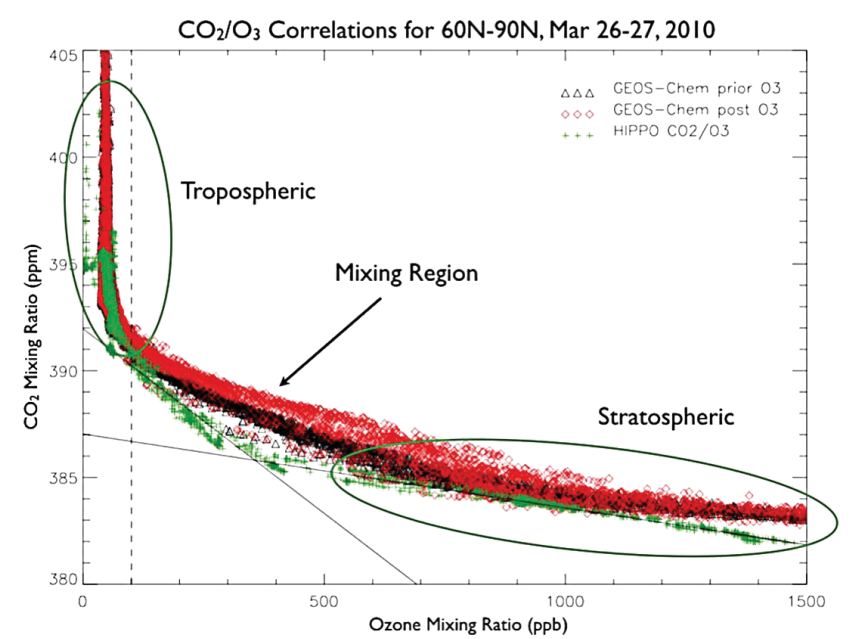

Figure 3. $\mathrm{CO}_{2} / \mathrm{O}_{3}$ correlations from GEOS-Chem (red) and HIPPO-3 (green) for 26-27 March 2010, poleward of $60^{\circ} \mathrm{N}$. The high $\mathrm{O}_{3}$ and low $\mathrm{CO}_{2}$ values are characteristic of stratospheric air, whereas the low $\mathrm{O}_{3}$ and high $\mathrm{CO}_{2}$ values indicate tropospheric air. The values in the UTLS represent a mixture of stratospheric and tropospheric air. The red diamonds represent the GEOS-Chem $\mathrm{CO}_{2} / \mathrm{O}_{3}$ correlations obtained after assimilation of the OSIRIS $\mathrm{O}_{3}$ data in the stratosphere. The two thin black lines show the fit to the HIPPO data in the stratospheric branch and in the mixing region. The vertical dashed line indicates the $100 \mathrm{ppb}$ threshold for $\mathrm{O}_{3}$, below which the air is considered tropospheric in origin.

aircraft data. In a separate study, (MacKenzie et al., 2015) used ACE-FTS $\mathrm{CO}$ and $\mathrm{O}_{3}$ data to evaluate the stratospheretroposphere mixing layer in the GEOS-Chem model. They found that vertical extent of the mixing layer simulated by the model agrees with that derived from ACE-FTS data. However, at high-latitudes the altitude of the mixing layer in the model is biased high relative to that from ACE-FTS, whereas at low-latitudes it is biased low.

Since $\mathrm{CO}_{2}$ and $\mathrm{O}_{3}$ are both long-lived tracers in the lower stratosphere, and their distributions largely reflect the influence of transport, we chose to optimize the modeled $\mathrm{O}_{3}$ distribution and use the observed $\mathrm{CO}_{2} / \mathrm{O}_{3}$ correlation to obtain an observation-based adjustment to the modeled $\mathrm{CO}_{2}$ distribution. To improve the modeled ozone distribution, we assimilated OSIRIS ozone observations using the GEOS-Chem $4 \mathrm{D}$-var system. The 4D-Var assimilation scheme adjusts the initial $\mathrm{O}_{3}$ conditions to optimize the model trajectory over the assimilation window. If the window is long compared to the lifetime of ozone, the assimilation system is unable to use the information from observations toward the end of the window to adjust the initial conditions, since that information is chemically destroyed. On the other hand, if the window is too short, there are fewer data available to adjust the state. In the high-latitude UTLS, the $\mathrm{O}_{3}$ lifetime is long, however, in the tropical middle troposphere, the $\mathrm{O}_{3}$ lifetime is about 3 weeks (Wang et al., 1998). Consequently, we chose a 2-week assimilation window, from 20 March to 2 April 2010. Furthermore,

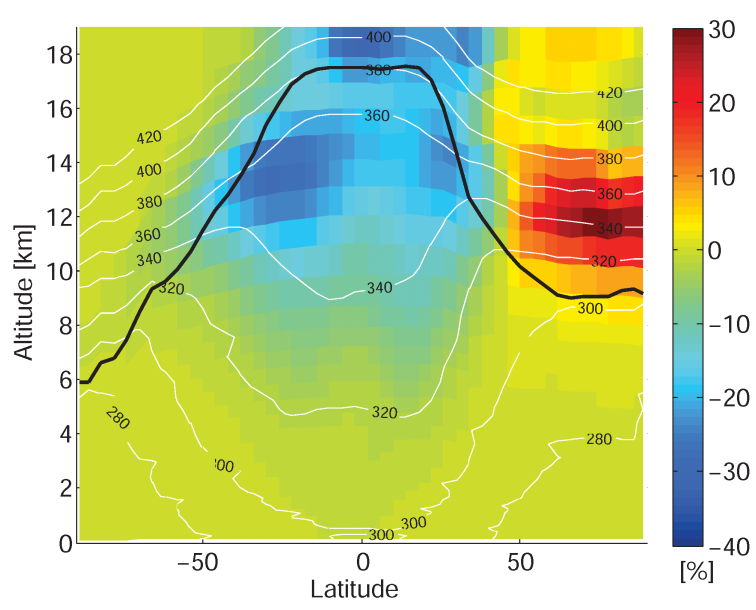

Figure 4. Zonal mean change in the GEOS-Chem $\mathrm{O}_{3}$ distribution as a result of the assimilation of OSIRIS $\mathrm{O}_{3}$ data. The assimilation was conducted for 20 March-2 April 2010. As in Fig. 1, the white lines indicate the zonal mean potential temperature in Kelvins (K) and the thick black line denotes the location of the tropopause in the model.

since the Arctic HIPPO measurements were made on 26 and 27 March, we chose the assimilation window so that the timing of the HIPPO data would fall at the midpoint of the window, providing the best constraint on the $\mathrm{O}_{3}$ distribution at that time.

The changes in the modeled $\mathrm{O}_{3}$ fields as a result of the assimilation are shown in Fig. 4. The assimilation increased $\mathrm{O}_{3}$ in the lowermost stratosphere by about 10-20\% and decreased it by as much as $40 \%$ in the tropical and subtropical UTLS. To evaluate the modeled $\mathrm{O}_{3}$ fields, we compared the a priori and a posteriori ozone fields with data from the ACEFTS instrument, shown in Fig. 5. The modeled ozone distributions were sampled at the ACE-FTS observation locations and times (we selected the model grid box consistent with the location of the $30 \mathrm{~km}$ tangent height). The comparisons shown used 31 ACE-FTS profiles between $55-65^{\circ} \mathrm{N}$ and 44 profiles between $65-75^{\circ} \mathrm{N}$ during the period 20 March to 3 April 2010. In the Arctic, between 100-20 hPa both the a priori and a posteriori ozone fields agree with the ACE-FTS data to within $10 \%$. At these altitudes, the a priori bias was $-2.7 \%$ between $55-65^{\circ} \mathrm{N}$ (Fig. 5a), while the a posteriori bias was $1 \%$. Between $65-75^{\circ} \mathrm{N}$, the a priori and a posteriori biases were $2.3 \%$ and $4.4 \%$, respectively. At lower altitudes, the model bias was larger, with the a priori model underestimating ACE-FTS $\mathrm{O}_{3}$ by as much as $30-40 \%$ near $200 \mathrm{hPa}$. The assimilation reduced the underestimate to within 15$25 \%$ of the ACE-FTS data. Despite this large residual bias at these levels, the assimilated ozone fields represent a significant improvement over the a priori in the lower stratosphere. It should be noted that because the data from both OSIRIS and ACE-FTS are limb measurements, the information ob- 

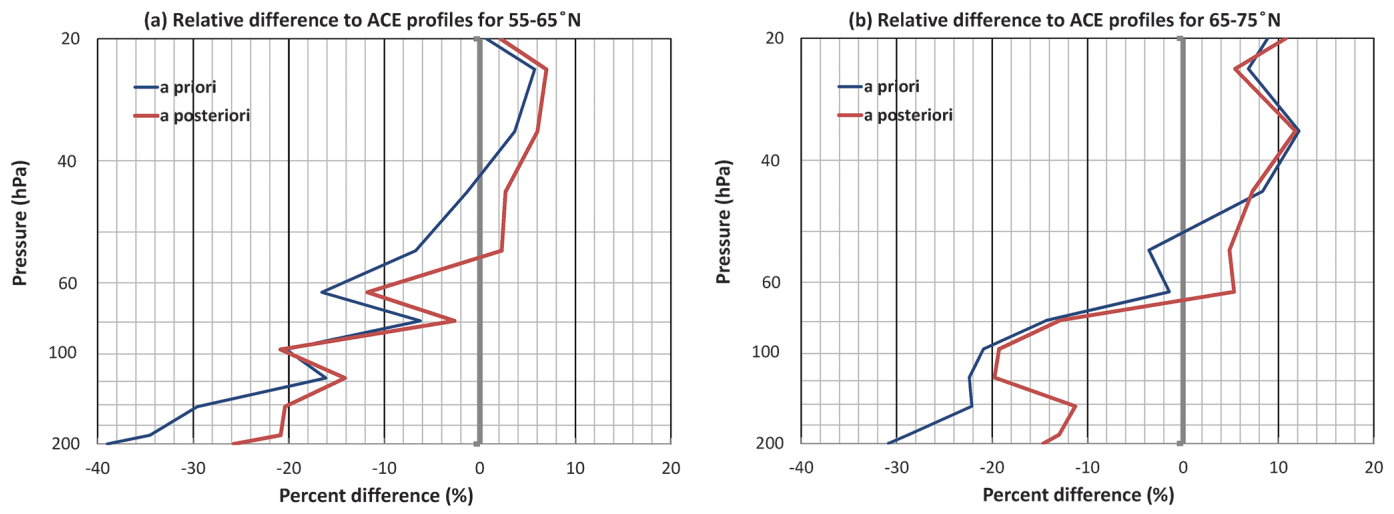

Figure 5. Relative difference between the a priori and a posteriori modeled $\mathrm{O}_{3}$ and ACE-FTS $\mathrm{O}_{3}$ data. Shown are the mean differences for latitudes between $55-65^{\circ} \mathrm{N}(\mathbf{a})$ and between $65-75^{\circ} \mathrm{N}(\mathbf{b})$.

tained from them is more limited at pressures of $200 \mathrm{hPa}$ and higher.

With the optimized stratospheric $\mathrm{O}_{3}$, we used the empirical fit between $\mathrm{CO}_{2}$ and $\mathrm{O}_{3}$ from the HIPPO $\mathrm{CO}_{2} / \mathrm{O}_{3}$ correlations to produce an adjustment to the modeled $\mathrm{CO}_{2}$ in the lower stratosphere. Examination of $\mathrm{CO}_{2} / \mathrm{O}_{3}$ correlations in the model at the locations of the HIPPO data and elsewhere across the modeled Arctic produced negligible differences in the correlations. Consequently, although the HIPPO measurements were localized over the Pacific (over Alaska on 26-27 March 2010), we applied the empirical fit throughout the Arctic to produce a zonal mean adjustment to the modeled $\mathrm{CO}_{2}$ profile in the Arctic. The zonal mean change in the vertical profile of $\mathrm{CO}_{2}$ in the Arctic as a result of the HIPPO-derived adjustment is shown in Fig. 6. The HIPPO $\mathrm{CO}_{2} / \mathrm{O}_{3}$ correlations suggest a steeper vertical gradient in $\mathrm{CO}_{2}$ across the tropopause, which is consistent with the results of MacKenzie et al. (2015) that showed that the stratosphere-troposphere mixing region in the model is biased high relative to the tropopause at high latitudes. We examined the $\mathrm{CO}_{2} / \mathrm{O}_{3}$ correlation throughout the month of March 2010 and found little variations in the correlations, so we applied the adjustment to the $\mathrm{CO}_{2}$ vertical distribution throughout March. This adjustment was then imposed in the modeled $\mathrm{CO}_{2}$ fields and we repeated the GOSAT inversion from Deng et al. (2014), but only for the growing season, March-August 2010, to assess the impact of this perturbation in $\mathrm{CO}_{2}$ in the Arctic UTLS on the inferred surface fluxes of $\mathrm{CO}_{2}$. This adjustment to the Arctic $\mathrm{CO}_{2}$ distribution corresponds to a sink in the global mass of $\mathrm{CO}_{2}$ of $0.6 \mathrm{Pg} \mathrm{C}$ in the GOSAT inversion analysis. Ideally, one would use seasonally varying $\mathrm{CO}_{2} / \mathrm{O}_{3}$ correlations to obtain the appropriate UTLS $\mathrm{CO}_{2}$ adjustment over the seasonal cycle. However, there was only one HIPPO campaign (in spring) in 2010. Consequently, as a first step in assessing the potential impact of this discrepancy in the UTLS on the flux estimates we chose to impose a constant adjustment to the $\mathrm{CO}_{2}$ distribution. It should be noted that if the UTLS discrepancy is due to excessive ver-

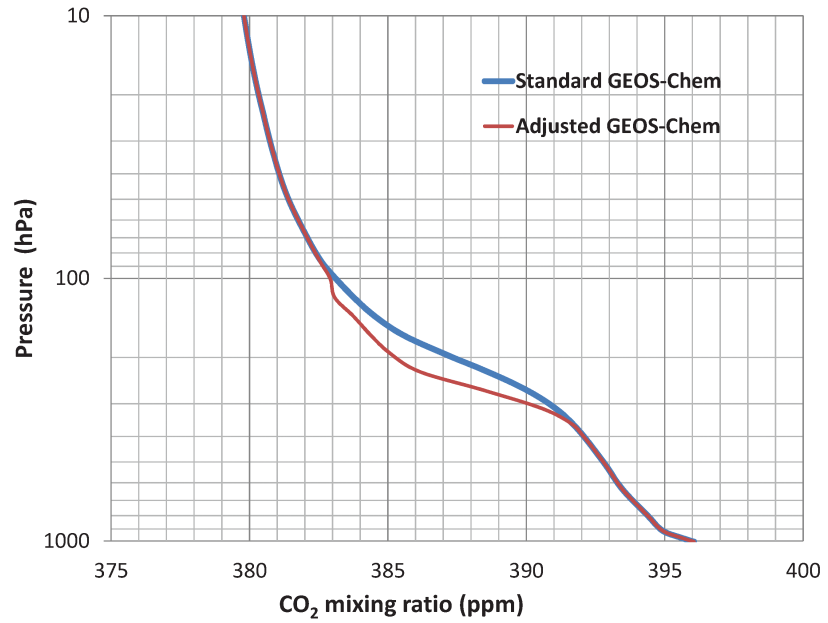

Figure 6. The mean profile of $\mathrm{CO}_{2}$ in the Arctic before (in blue) and after (in red) the adjustment in $\mathrm{CO}_{2}$ in the UTLS based on the HIPPO- $3 \mathrm{CO}_{2} / \mathrm{O}_{3}$ correlations.

tical mixing then we would expect it to be larger when the vertical gradient in $\mathrm{CO}_{2}$ is large. This means that we would expect the discrepancy to be present from March until summer, by July or August, when the summertime drawdown reverses the vertical gradient in $\mathrm{CO}_{2}$ in the troposphere.

\subsection{Passive tracer experiments}

To help understand the potential impact of the adjustment to $\mathrm{CO}_{2}$ in the Arctic UTLS shown in Fig. 6, we conducted forward sensitivity analyses using a passive $\mathrm{CO}_{2}$-like tracer in the model. As mentioned above, the Arctic UTLS adjustment leads a total atmospheric $\mathrm{CO}_{2}$ mass decrease of 0.60 between March-August 2010, so for the passive tracer experiment we imposed an equivalent source. This way, the source matches the change in $\mathrm{CO}_{2}$ in the UTLS shown in Fig. 6. As in the inversion analysis, we impose the adjustment across the whole Arctic, but here it is a source, whereas it is a sink in the in- 

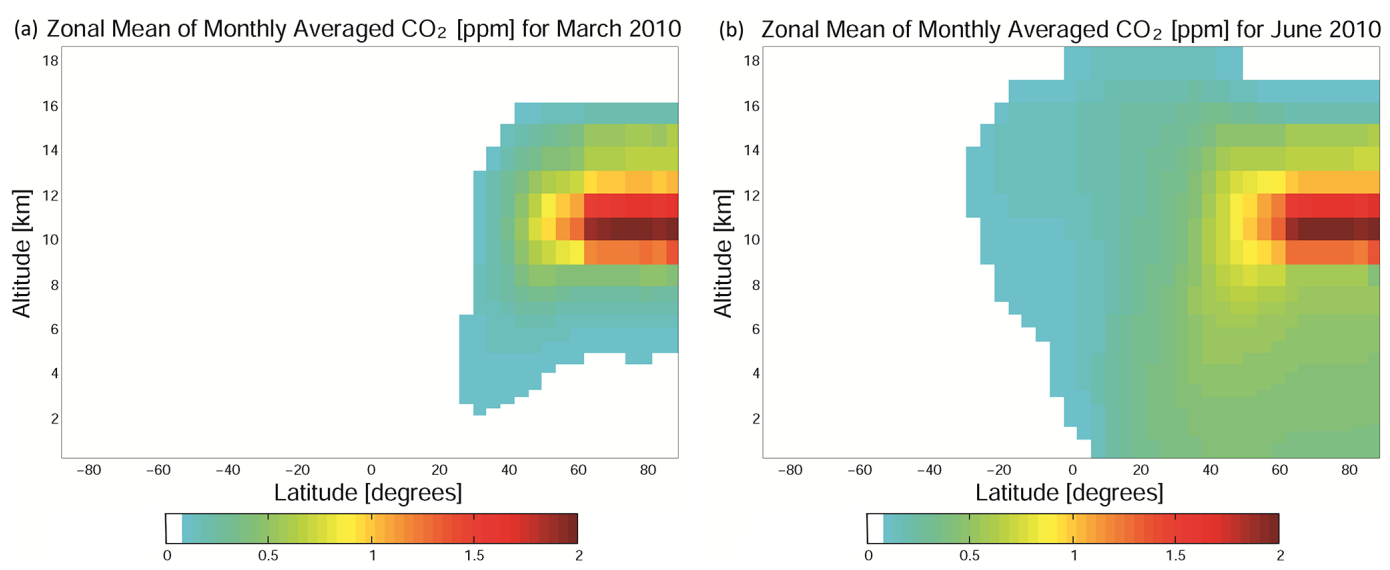

Figure 7. Monthly averaged, zonal mean distribution of a passive tracer with a constant source equivalent to the $\mathrm{CO}_{2}$ adjustment in the Arctic UTLS for March-August 2010.

version analysis. The zonal mean distribution of the passive tracer is shown in Fig. 7 for March and June 2010. Within the first month, there is significant transport of the stratospheric $\mathrm{CO}_{2}$ down into the mid-latitude and subtropical troposphere. In summer, there is transport to the Southern Hemisphere in the tropical UTLS, as described by Miyazaki et al. (2008). By June the tracer has been transported south as far as $30^{\circ} \mathrm{S}$ (Fig. 7b), and by August, the tracer distribution extends as far as $60^{\circ} \mathrm{S}$ (not shown).

In Fig. 8 we have plotted the distribution of the tracer in terms of the column averaged dry mole fraction $\left(\mathrm{XCO}_{2}\right)$. We have sampled the tracer distribution at the GOSAT observation locations and times and applied the GOSAT averaging kernels to smooth the tracer in a manner that is consistent with the vertical sensitivity of the GOSAT retrievals. Although the imposed source is located mainly in the stratosphere, its impact on the $\mathrm{CO}_{2}$ column, as reflected in the $\mathrm{XCO}_{2}$ values, is not negligible. By June, the perturbation in $\mathrm{XCO}_{2}$ exceeds $0.5 \mathrm{ppm}$ in the mid- and high-latitudes of the Northern Hemisphere. As a result of the inter-hemispheric transport in the tropical UTLS, we see small corrections of about $0.1-0.2 \mathrm{ppm}$ in $\mathrm{XCO}_{2}$ in the southern tropics and subtropics. In June, the $\mathrm{XCO}_{2}$ changes are confined to equatorward of $30^{\circ} \mathrm{S}$, reflecting the southern extent of the tracer transport in the upper troposphere (Fig. 7b). However, by August, the influence of the Arctic source is reflected in the $\mathrm{XCO}_{2}$ values across all of South America and Australia. We note that even though the tracer is accumulating in the troposphere over the course of the run, the impact on $\mathrm{XCO}_{2}$ in the Southern Hemisphere in August is still small, about 0.1$0.2 \mathrm{ppm}$. The results in Fig. 8 are interesting, nevertheless, as they demonstrate that the perturbations in $\mathrm{CO}_{2}$ in the UTLS can have a noticeable impact on $\mathrm{XCO}_{2}$ values, which have implications for interpreting differences in inversion analyses using $\mathrm{XCO}_{2}$ and in situ surface data.

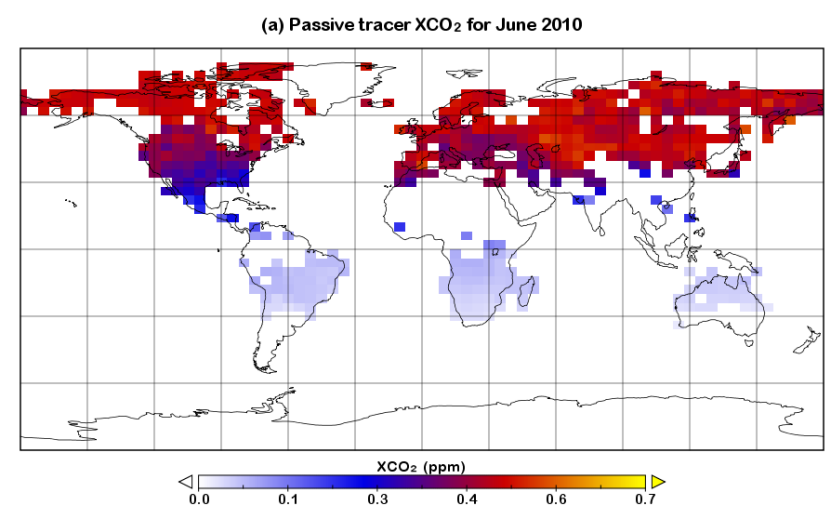

(b) Passive tracer $\mathrm{XCO}_{2}$ for August 2010

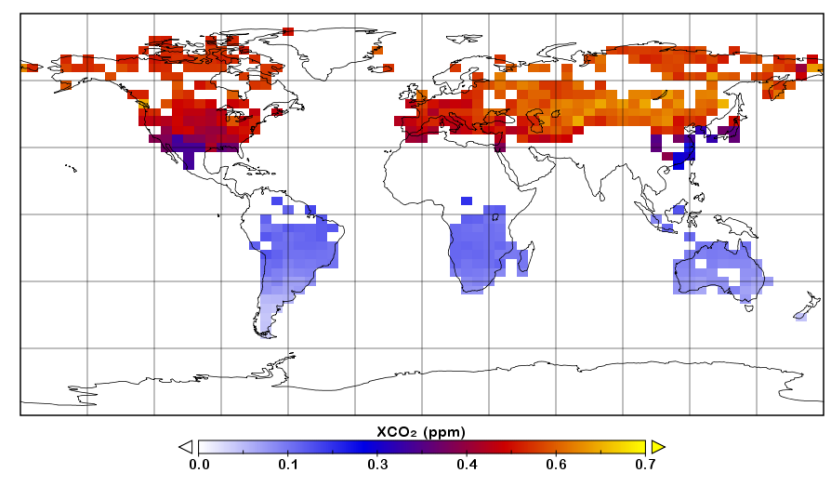

Figure 8. Monthly mean distribution of a passive tracer with a constant source equivalent to the $\mathrm{CO}_{2}$ adjustment in the Arctic UTLS for March-August 2010. The tracer distribution was sampled at the GOSAT observation locations and times and vertically integrated, using the GOSAT averaging kernels, to produce $\mathrm{XCO}_{2}$ values.

\subsection{Inversion analyses}

Using the inversion approach of Deng et al. (2014), we assimilated the ACOS GOSAT $\mathrm{XCO}_{2}$ from 1 March-31 August 2010, with the reduction in UTLS $\mathrm{CO}_{2}$ in the Arctic. 


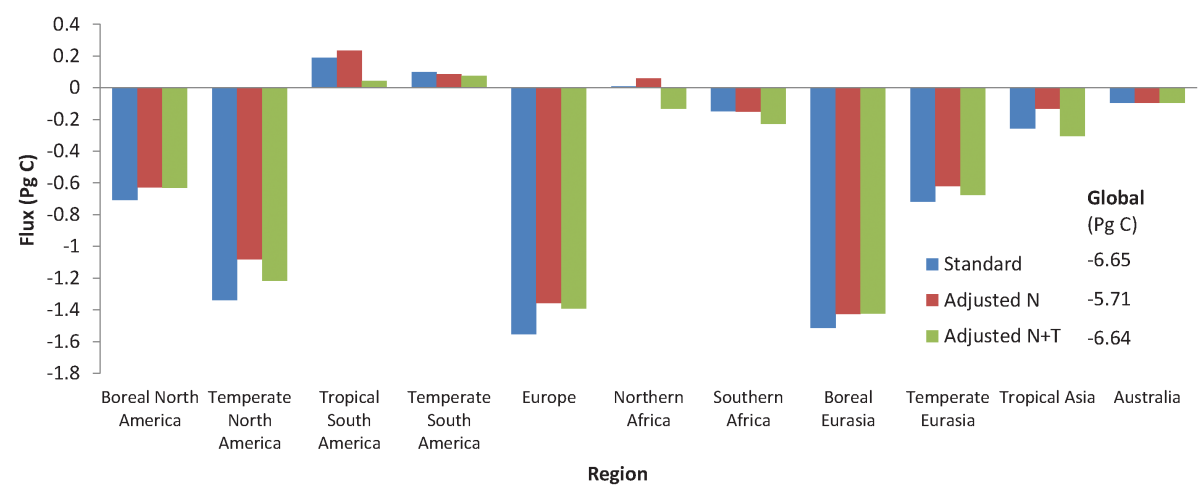

Figure 9. Regional $\mathrm{CO}_{2}$ flux estimates for March to August 2010 inferred from GOSAT $\mathrm{XCO}_{2}$ using the standard inversion approach (denoted Standard), with an imposed sink in $\mathrm{CO}_{2}$ in the Arctic UTLS (denoted Adjusted N), and with the addition of uniform source in the upper troposphere in the northern tropics (denoted Adjusted $\mathrm{N}+\mathrm{T}$ )

Shown in Fig. 9 are the inversion results, aggregated to the TransCom regions. Without the Arctic UTLS adjustment, we obtained an estimated land sink of $\mathrm{CO}_{2}$ of $-6.65 \mathrm{PgC}$ for March-August 2010. With the imposed reduction in the $\mathrm{CO}_{2}$ in the Arctic, the estimated land sink was reduced to $-5.71 \mathrm{PgC}$. The largest absolute changes in the regional flux estimates were obtained for temperate North America (from -1.34 to $-1.08 \mathrm{Pg} \mathrm{C}$ ) and Europe (from -1.55 to $-1.36 \mathrm{PgC}$ ). The flux estimate for the other regions, such as Boreal North America, Boreal Eurasia, temperate Eurasia, and tropical Asia, all changed by about $0.1 \mathrm{Pg} \mathrm{C}$. As a relative change, the difference in the flux estimate for tropical Asia was large, with the flux decreasing by a factor of two from -0.26 to $-0.13 \mathrm{PgC}$. In the rest of the tropics, the largest change was for tropical South America, for which the flux estimate increased $23 \%$, from 0.19 to $0.23 \mathrm{Pg} \mathrm{C}$. The flux estimate for northern Africa increased from 0.01 to $0.06 \mathrm{Pg} \mathrm{C}$.

Deng et al. (2014) showed that the GOSAT data suggest that the bottom-up biospheric fluxes used in this version of GEOS-Chem underestimate the summertime sinks of $\mathrm{CO}_{2}$. For example, their GOSAT-derived estimate for the June sink of $\mathrm{CO}_{2}$ for temperate North America was $-0.5 \mathrm{Pg} \mathrm{C}$ compared to their a priori of about $-0.3 \mathrm{Pg} \mathrm{C}$. Since, as shown in Fig. 6, much of the perturbation in $\mathrm{CO}_{2}$ in the Arctic UTLS is transported down in the troposphere, the imposed reduction in UTLS $\mathrm{CO}_{2}$ during the growing season requires weaker surface sinks to bring the model into agreement with the GOSAT data. In the experiment here, the largest changes are obtained for the mid-latitude flux regions in North America and Europe, due to transport of the lower stratospheric adjustment down, along the isentropes (shown in Fig. 4), into the middle and upper troposphere of the mid-latitudes and subtropics. We believe that the large change obtained for the tropical Asian flux may be due to the influence of STE associated with the Asian monsoon (e.g. Postel and Hitchman, 1999; Shuckburgh et al., 2009).

In general, the inversion results show that reducing the $\mathrm{CO}_{2}$ mixing ratio in the Arctic UTLS decreased the sinks in most northern land regions and increased the sources in the tropics. As mentioned above, the decreased northern land sinks are due to the fact that the imposed UTLS sink compensates for the summertime uptake at the surface. We believe that the increased tropical sources are due to the fact that the UTLS sink exacerbates the underestimate of $\mathrm{CO}_{2}$ in the model in the tropical upper troposphere. Figure 2 shows that there is a residual negative bias in $\mathrm{CO}_{2}$, relative to the HIPPO data, in the upper troposphere in the northern tropics and subtropics in the standard inversion. As shown by the transport pattern in Fig. 7b, the imposed reduction in the UTLS $\mathrm{CO}_{2}$ will exacerbate this bias, forcing the inversion to compensate by increasing the tropical sources. This underestimate in tropical $\mathrm{CO}_{2}$ is consistent with the argument that the lowermost stratospheric bias shown in Figs. 3 and 6 is due to excessive mixing across the tropopause in the subtropics. Excessive STE would result in enhanced $\mathrm{CO}_{2}$ (and reduced $\mathrm{O}_{3}$ ) in the extratropical lowermost stratosphere and reduced $\mathrm{CO}_{2}$ (and enhanced $\mathrm{O}_{3}$ ) in the tropical upper troposphere. Indeed, assimilation of the OSIRIS data, as shown in Fig. 4, increased ozone in the extratropical lowermost stratosphere and decreased it in the upper tropical troposphere. Consequently, the imposed reduction in $\mathrm{CO}_{2}$ in the Arctic UTLS should be accompanied by an increase in $\mathrm{CO}_{2}$ in the tropical and subtropical upper troposphere.

Unlike the extratropical UTLS, use of the $\mathrm{CO}_{2} / \mathrm{O}_{3}$ correlations in the tropical UTLS to adjust the $\mathrm{CO}_{2}$ distribution is challenging because of the effects of convective transport and the chemical production of $\mathrm{O}_{3}$ on the tracer-tracer relationship in the tropical upper troposphere. Therefore, as a first step, we chose to impose a uniform source of $\mathrm{CO}_{2}$ of about $0.25 \mathrm{ppm}$ between $8-20^{\circ} \mathrm{N}$ and about $5-8 \mathrm{~km}$, to remove the mean bias between the model and the HIPPO $\mathrm{CO}_{2}$ data in this region. This constant $0.25 \mathrm{ppm}$ adjustment corresponds to a total source of $0.55 \mathrm{Pg} \mathrm{C}$ for March-August 2010, and almost balances the imposed Arctic sink. The inversion results with the combined UTLS sink in the Arctic and the tropical source are shown in Figs. 9 and 10. The global land sink was 

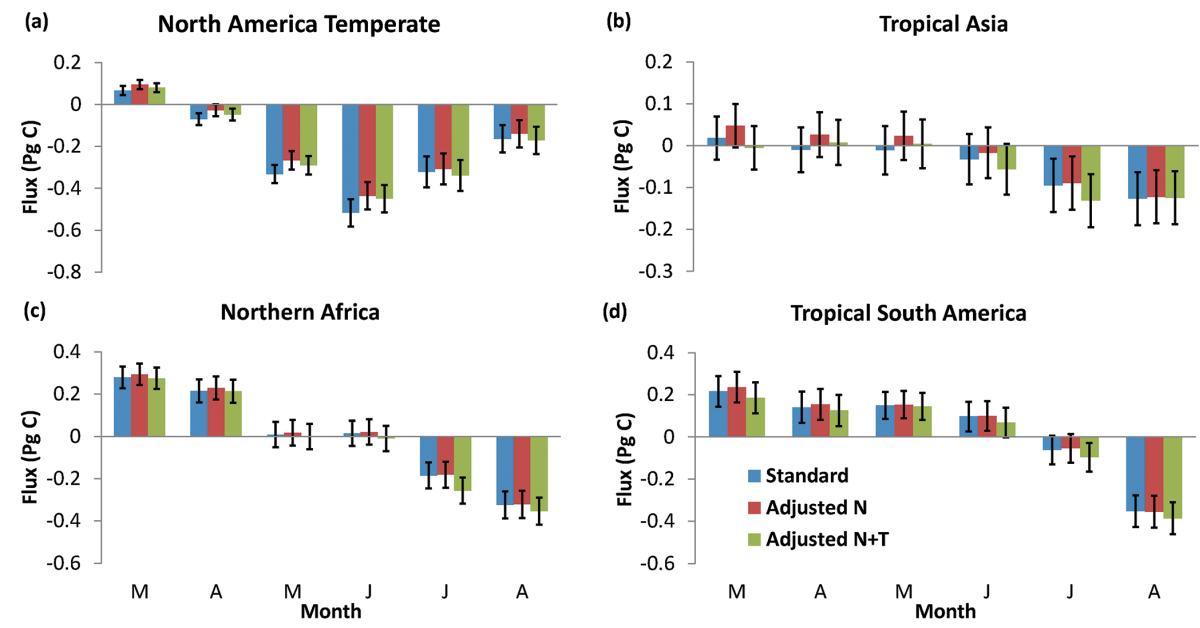

Figure 10. Monthly mean $\mathrm{CO}_{2}$ flux estimates and their uncertainties for (a) temperate North America, (b) tropical Asia, (c) northern Africa, and (d) tropical South America. As in Fig. 9, shown are the results from using the standard inversion (denoted Standard), with an imposed sink in $\mathrm{CO}_{2}$ in the Arctic UTLS (denoted Adjusted $\mathrm{N}$ ), and with the addition of uniform source in the upper troposphere in the northern tropics (denoted Adjusted N+T).

estimated as $-6.64 \mathrm{PgC}$ with the combined Arctic sink and tropical source, a $0.01 \mathrm{Pg} \mathrm{C}$ difference from $-6.65 \mathrm{Pg} \mathrm{C}$ obtained in the standard inversion. The flux estimates for the three most northern land regions were relatively unchanged with the tropical adjustment. Europe, for example, was estimated as a sink of $-1.39 \mathrm{PgC}$ with the combined source and the sink compared to $-1.36 \mathrm{Pg} \mathrm{C}$ with just the Arctic sink. Small changes were obtained from northern temperate regions. Temperate North America, for example, was inferred as a sink of $-1.22 \mathrm{PgC}$ with the combined Arctic and tropical adjustments compared to $-1.08 \mathrm{Pg} \mathrm{C}$ with just the Arctic adjustment. Although the global land sink with the Arctic and tropical adjustment was consistent with that estimated in the standard inversion, we found that the total northern land sink (for March-August) was $0.98 \mathrm{Pg} \mathrm{C}$ weaker with the Arctic and tropical adjustment than in the standard inversion. This large latitudinal change in the land sink is due to the fact that a stronger extratropical drawdown during the growing season is required to account for the high-latitude UTLS bias in the standard inversion.

As expected, the largest relative differences with the addition of the tropical source were for the tropical regions. For tropical South America, the flux estimate increased by $23 \%$ with only the Arctic sink, whereas it was reduced by $77 \%$ with the combined Arctic sink and tropical source. For northern Africa, where the fluxes are small for March-August, the flux estimates changed sign, going from $0.06 \mathrm{PgC}$ with the Arctic sink to $-0.13 \mathrm{Pg} C$ with the combined Arctic sink and tropical source. With only the Arctic sink, we found that the flux estimate for tropical Asia was reduced by a factor of two. However, the addition of the tropical source compensated for the influence of the Arctic sink on this region, producing a flux estimate of $-0.30 \mathrm{PgC}$, which is a slightly stronger sink than that inferred in the standard inversion $(-0.26 \mathrm{Pg} \mathrm{C})$. Despite the apparent consistency between the tropical Asian flux estimates from the standard inversion and from the inversion with the combined source and sink, the transition from being a source to a sink for $\mathrm{CO}_{2}$ is impacted by the specification of the tropical source. The standard inversion suggested a weak source for March, which shifted to a sink in April. However, the inversion with the combined source and sink produced a weak sink in March, which became a weak source in April, before strongly transitioning to a sink in June. Because the a posteriori flux uncertainties are largest in the tropics, the differences in the flux estimates can be small relative to the a posteriori uncertainties for the tropical regions. This is particularly the case for tropical Asia. For northern Africa, the largest absolute flux difference obtained with the tropical source and Arctic sink, compared to the standard inversion, is for July, and that exceeds the flux uncertainty. In contrast, in the extratropics, for temperate North America, for example, with the Arctic sink the changes are larger than the flux uncertainties for March through June. With the combined source and sink, the temperate North American flux changes are larger than the uncertainties in June, when the sink is at a maximum. Although the relative flux differences are small for some regions, the discrepancies represent significant spatially dependent biases, which have implications for the latitudinal distribution of the estimated sources and sinks.

\subsection{Impact of model resolution}

To assess the potential impact of model resolution, we doubled the model resolution to $2^{\circ} \times 2.5^{\circ}$ and repeated the forward model simulation from 1 July 2009 to 31 December 2010. Because of the large number of iterations required 


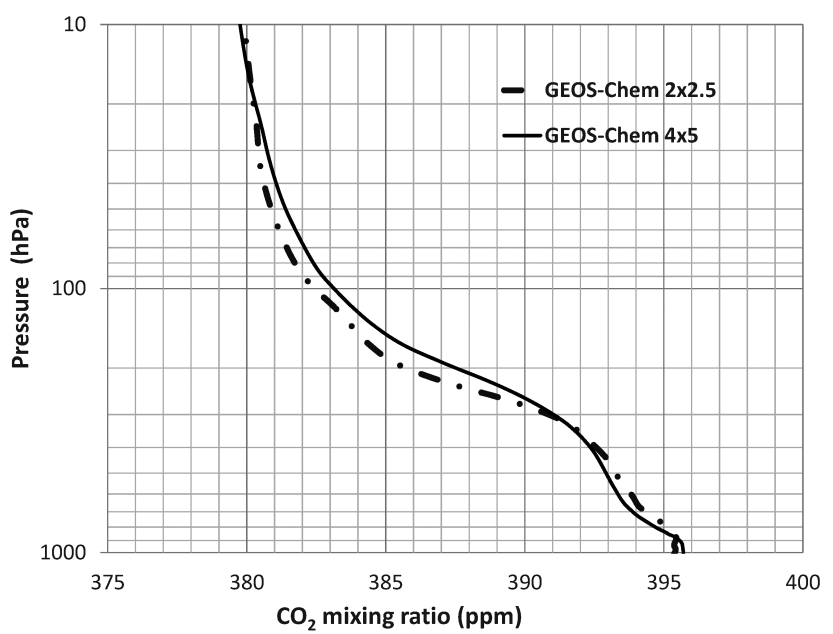

Figure 11. Zonal mean profiles of $\mathrm{CO}_{2}$ at $75^{\circ} \mathrm{N}$ on 1 April 2010 from the GEOS-Chem $4^{\circ} \times 5^{\circ}$ and $2^{\circ} \times 2.5^{\circ}$ simulations. The simulations began with the same initial conditions on 1 July 2009. The fossil fuel, biofuel, ocean, and biospheric fluxes used in the simulations were scaled based on the a posteriori scaling factors from the GOSAT $\mathrm{XCO}_{2}$ inversion. The biomass burning fluxes, however, were not scaled.

for minimizing the cost function, it is computationally expensive to carry out the global inversion analysis at the $2^{\circ} \times 2.5^{\circ}$ resolution. As a result, we focus here on a comparison of the forward model simulation. Shown in Fig. 11 is the zonal mean vertical profile of $\mathrm{CO}_{2}$ at $75^{\circ} \mathrm{N}$ on 1 April 2010. The model configuration used to produce the results in Fig. 11 is similar to, but not identical to that used for the results in Figs. 1-3 and 6. Here we use the a posteriori scaling factors (the ratio of the a posteriori to a priori fluxes) from the standard $\mathrm{CO}_{2}$ inversion to scale the fossil fuel, biofuel, ocean, and biospheric $\mathrm{CO}_{2}$ fluxes, but the biomass burning emissions are not scaled. As shown in Fig. 11, the higher resolution simulation produced a steeper gradient in $\mathrm{CO}_{2}$ than the low-resolution simulation, which is consistent with excessive vertical mixing in the $4^{\circ} \times 5^{\circ}$ simulation. Examination of the latitudinal distribution in the UTLS, shown in Fig. 12 reveals more $\mathrm{CO}_{2}$ in the upper tropical and subtropical troposphere and less $\mathrm{CO}_{2}$ in the high-latitude lower stratosphere in the $2^{\circ} \times 2.5^{\circ}$ run compared to the $4^{\circ} \times 5^{\circ}$ run; the latitudinal gradient in the Northern Hemisphere UTLS is weaker in the low-resolution simulation.

In Table 1 we have listed the mean differences between the standard a posteriori $\mathrm{CO}_{2}$ and the HIPPO data above $8 \mathrm{~km}$, binned into four latitudinal bins. As discussed above, the largest biases are in the polar region, with a positive bias of $1.72 \mathrm{ppm}$ between $60-90^{\circ} \mathrm{N}$. In the lower latitudes the model is biased low, with a bias of $-0.09 \mathrm{ppm}$ between $0-15^{\circ} \mathrm{N}$ and $-0.31 \mathrm{ppm}$ between $15-45^{\circ} \mathrm{N}$. Also listed in Table 1 are mean differences between the $4^{\circ} \times 5^{\circ}$ and $2^{\circ} \times 2.5^{\circ}$ simulations. Between $60-90^{\circ} \mathrm{N}$ the low-resolution simulation is

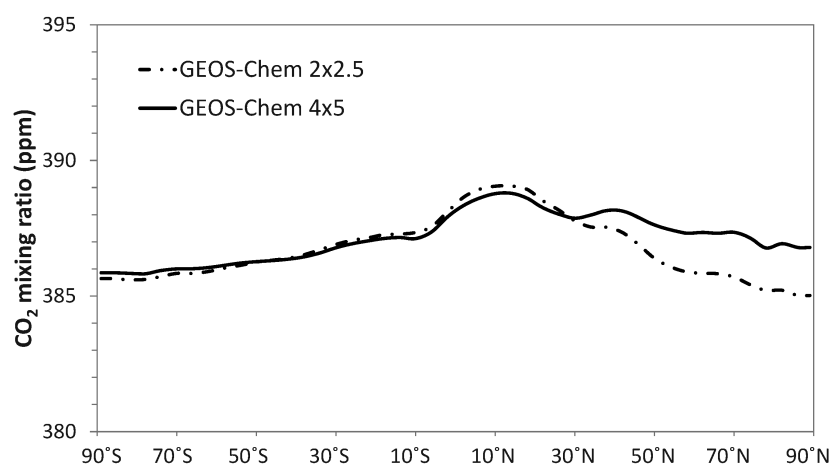

Figure 12. Latitudinal cross section of zonal mean $\mathrm{CO}_{2}$ at $12 \mathrm{~km}$ on 1 April 2010 from the GEOS-Chem $4^{\circ} \times 5^{\circ}$ and $2^{\circ} \times 2.5^{\circ} \mathrm{sim}-$ ulations.

higher by $0.55 \mathrm{ppm}$, which is almost a third of the high bias between the low-resolution simulation and the HIPPO data. In the tropics $\left(0-15^{\circ} \mathrm{N}\right)$, the difference between the $4^{\circ} \times 5^{\circ}$ and $2^{\circ} \times 2.5^{\circ}$ simulations is equivalent to the differences between the $4^{\circ} \times 5^{\circ}$ simulation and the HIPPO data.

\section{Conclusions}

We have evaluated the GEOS-Chem $\mathrm{CO}_{2}$ simulation in the extratropical UTLS using aircraft observations from the HIPPO-3 campaign in March 2010 and found that the model overestimates $\mathrm{CO}_{2}$ in the lowermost stratosphere in the Arctic. Comparison of the modeled and observed correlations between $\mathrm{CO}_{2}$ and $\mathrm{O}_{3}$, suggest a discrepancy in mixing in the UTLS in the model. To obtain an observation-based adjustment to $\mathrm{CO}_{2}$ in the model, we assimilated $\mathrm{O}_{3}$ data from the OSIRIS instrument to improve the stratospheric $\mathrm{O}_{3}$ in the model and then used the assimilated $\mathrm{O}_{3}$ together with the HIPPO $\mathrm{CO}_{2} / \mathrm{O}_{3}$ correlation to infer an adjustment to the modeled $\mathrm{CO}_{2}$ in the Arctic. The HIPPO-based adjustment to the modeled $\mathrm{CO}_{2}$ resulted in an increase in the vertical gradient in $\mathrm{CO}_{2}$ across the Arctic tropopause.

To assess the potential impact of these changes in $\mathrm{CO}_{2}$ on regional $\mathrm{CO}_{2}$ flux estimates, we conducted inversion analyses using GOSAT $\mathrm{XCO}_{2}$ data, with and without the $\mathrm{CO}_{2}$ adjustment in the Arctic UTLS. Because of the lack of data to evaluate the $\mathrm{CO}_{2} / \mathrm{O}_{3}$ correlations over the seasonal cycle, the adjustment in the Arctic UTLS was assumed to be constant over the assimilation period, from March-August 2010, representing a total sink of $0.60 \mathrm{Pg} \mathrm{C}$ in the Arctic UTLS. We found that this adjustment in Arctic $\mathrm{CO}_{2}$ resulted in a reduction in the inferred flux of $\mathrm{CO}_{2}$ from temperate North America and Europe during the growing season of 19 and $13 \%$ respectively, compared to the standard inversion (without the imposed sink). For tropical Asia, there was a factor of two reduction in the estimated flux.

If the bias in $\mathrm{CO}_{2}$ reflects the influence of excessive STE, one would expect the overestimate in $\mathrm{CO}_{2}$ in the extratropi- 
Table 1. Mean differences in $\mathrm{CO}_{2}(\mathrm{ppm})$ between GEOS-Chem and HIPPO and between the GEOS-Chem $4^{\circ} \times 5^{\circ}$ and $2^{\circ} \times 2.5^{\circ}$ simulations.

\begin{tabular}{|c|c|c|c|c|c|c|c|}
\hline \multicolumn{4}{|c|}{ GEOS-Chem (standard) - HIPPO Observation } & \multicolumn{4}{|c|}{ GEOS-Chem $4 \times 5$ - GEOS-Chem $2 \times 2.5$} \\
\hline $0-15^{\circ} \mathrm{N}$ & $15-45^{\circ} \mathrm{N}$ & $45-60^{\circ} \mathrm{N}$ & $60-90^{\circ} \mathrm{N}$ & $0-15^{\circ} \mathrm{N}$ & $15-45^{\circ} \mathrm{N}$ & $45-60^{\circ} \mathrm{N}$ & $60-90^{\circ} \mathrm{N}$ \\
\hline-0.09 & -0.31 & 1.60 & 1.72 & -0.09 & -0.23 & -0.25 & 0.55 \\
\hline \multicolumn{2}{|c|}{-0.23} & \multicolumn{2}{|c|}{1.68} & \multicolumn{2}{|c|}{-0.18} & \multicolumn{2}{|c|}{0.29} \\
\hline
\end{tabular}

cal lower stratosphere to be accompanied by an overestimate in $\mathrm{CO}_{2}$ in the tropical and subtropical upper troposphere. Indeed, we find that the modeled $\mathrm{CO}_{2}$ is biased low relative to the HIPPO data in these regions. Also, relative to the OSIRIS data, the modeled $\mathrm{O}_{3}$ is biased low in the extratropical lower stratosphere and high in the tropical and subtropical upper troposphere, which is consistent with excessive STE. We conducted a sensitivity experiment in which we corrected the underestimate in $\mathrm{CO}_{2}$ in the low-latitude upper troposphere by imposing a uniform source of $\mathrm{CO}_{2}$ of $0.55 \mathrm{PgC}$ (an adjustment of $0.25 \mathrm{ppm}$ ) for March-August 2010 in the tropical upper troposphere to remove the mean difference between the HIPPO data and the a posteriori $\mathrm{CO}_{2}$ from the standard GOSAT inversion. With the extratropical sink and tropical source in the UTLS, the $\mathrm{CO}_{2}$ source inferred from tropical South America was reduced by $77 \%$. In contrast, with only the Arctic sink it was increased by $23 \%$. For tropical Asia, the total estimated flux with extratropical sink and tropical source in the UTLS was close to the estimate in the standard inversion. Although the imposed sources and sinks were ad hoc, due to the lack of data to better quantify the evolution of the model errors over the seasonal cycle, the results here illustrate that discrepancies in the $\mathrm{CO}_{2}$ distribution in the UTLS can impact the regional $\mathrm{CO}_{2}$ flux estimates using satellite data, and point to the need to better characterize model errors in the UTLS.

Inversion analyses using GOSAT $\mathrm{XCO}_{2}$ data tend to produce stronger sinks in the extratropical Northern Hemisphere and weaker sources in the tropics compared to those using the surface flask data (Houweling et al., 2015). In our analysis we found that with the combined Arctic and tropical adjustment, the March-August sink in northern lands was $0.98 \mathrm{Pg} \mathrm{C}$ weaker than in our standard inversion, even though the estimated total global sink in the two inversions were similar. Our results suggest that the high-latitude UTLS discrepancy could result in a latitudinal redistribution of mass in flux inversions, and we would expect the $\mathrm{XCO}_{2}$ inversions to be more sensitive to the UTLS discrepancies than the flask inversions. Because we have assumed that the adjustments are constant over the assimilation period, the changes in the flux estimates reported here might be an upper limit for the impact of these discrepancies, but we need to better characterize the spatio-temporal evolution of the UTLS biases to properly quantify their impact.
As we noted in the introduction, the $\mathrm{CO}_{2}$ distribution in the extratropical UTLS in winter and spring represents a balance between a positive tendency associated with largescale eddies and a negative tendency due to the transport by the mean meridional circulation (Miyazaki et al., 2008). The meridional circulation is, in part, driven by the large-scale eddies, and the balance between the two tendency terms will vary from model to model. It is possible that the inability of GEOS-Chem to reproduce the HIPPO $\mathrm{CO}_{2} / \mathrm{O}_{3}$ correlations in the extratropical UTLS may be due to discrepancies in either the large-scale eddies or the meridional circulation in the model. On the one hand, GEOS-Chem is driven by assimilated meteorological fields, so it is expected that the model will capture the large-scale eddies well. On the other hand, it is known that CTMs, which are driven by reanalyses, capture vertical transport in the UTLS less well than free running general circulation models because the data assimilation systems introduce imbalance between the temperature and wind fields (Douglass et al., 2003). It is because of this that CTMs generally underestimate the mean age of air in the stratosphere.

Other potential sources of discrepancy in the $\mathrm{CO}_{2}$ distribution are the numerical scheme used in the model and the resolution of the model simulation. Prather et al. (2008) compared the $\mathrm{CO}_{2}$ simulations from two CTMs using the same meteorological fields and $\mathrm{CO}_{2}$ fluxes, but with different numerical schemes. One model, the Global Modeling Initiative (GMI) CTM, used the numerical transport scheme by Lin and Rood (1996), whereas the other model, the University of California, Irvine (UCI) CTM, used the Second-Order Moments (SOM) scheme by Prather (1986). At a resolution of $5^{\circ} \times 4^{\circ}$, the GMI model, with the Lin and Rood (1996) scheme, was more diffusive, producing a weaker seasonal cycle in $\mathrm{CO}_{2}$ and higher $\mathrm{CO}_{2}$ values in the stratosphere. Prather et al. (2008) found that doubling the resolution of the models to $2^{\circ} \times 2.5^{\circ}$ reduced the discrepancies, but the GMI model still had numerical errors that were twice as large as those in the UCI model. We found that doubling our model resolution to $2^{\circ} \times 2.5^{\circ}$ increased the vertical gradient in $\mathrm{CO}_{2}$ in the high latitudes, and reduced the $\mathrm{CO}_{2}$ loading in the highlatitude lower stratosphere. The $4^{\circ} \times 5^{\circ}$ simulation overestimated the Arctic $\mathrm{CO}_{2}$ (averaged $60-90^{\circ} \mathrm{N}$ and above $8 \mathrm{~km}$ ) by $0.55 \mathrm{ppm}$, relative to the $2^{\circ} \times 2.5^{\circ}$ simulation which is almost a third of the high bias between the low-resolution 
simulation and the HIPPO data. In the tropics $\left(0-15^{\circ} \mathrm{N}\right)$, the difference between the $4^{\circ} \times 5^{\circ}$ and $2^{\circ} \times 2.5^{\circ}$ simulations is equivalent to the differences between the $4^{\circ} \times 5^{\circ}$ simulation and the HIPPO data. In contrast, the $4^{\circ} \times 5^{\circ}$ was biased low by $0.23 \mathrm{ppm}$ relative to the $2^{\circ} \times 2.5^{\circ}$ simulation between $15-45^{\circ} \mathrm{N}$, which is equivalent to the differences between the $4^{\circ} \times 5^{\circ}$ simulation and the HIPPO data, suggesting that the mixing is excessive in the low-resolution simulation.

There has been a number of studies looking at the impact of transport discrepancies in the UTLS on the distribution of $\mathrm{O}_{3}$ and other long-lived tracers, using aircraft, balloon, and satellite observations (e.g., Considine et al., 2008; Strahan and Polansky, 2006). But additional attention is needed to understand the impact of these discrepancies in the context of $\mathrm{CO}_{2}$ flux inversions. We expect that the discrepancies identified here will be more of an issue for inversion analyses using satellite data than those using surface data, since all thermal infrared and shortwave infrared, nadir satellite retrievals have sensitivity to $\mathrm{CO}_{2}$ in the UTLS. Based on our results, it is unclear the degree to which further increases in the spatial resolution of the model simulation will mitigate the biases in the UTLS. Additional studies using GEOSChem at higher spatial resolution, such as at the native resolution of $0.5^{\circ} \times 0.67^{\circ}$ would be helpful. Also, additional data are needed to better evaluate the model performance in the UTLS. High-resolution $\mathrm{CO}_{2}$ profile measurements across the UTLS would be useful. Simultaneous satellite measurements of $\mathrm{CO}_{2}, \mathrm{O}_{3}$ and other long-lived tracers from instruments such as limb sounders, would enable us to better exploit tracer-tracer correlations to evaluate model transport in the UTLS in the context of the $\mathrm{CO}_{2}$ flux inversions. For example, $\mathrm{CO}_{2}$ vertical profiles have also been retrieved from ACE-FTS (Sioris et al., 2014); however the data are currently sparse due to the initial cloud filtering method used, and thus were not used in the current work. Efforts are underway to retrieve profiles down to cloud tops, so that fewer profiles are lost, which could aid in future analyses.

Acknowledgements. This work was funded by the Canadian Space Agency (CSA), the Natural Sciences and Engineering Research Council of Canada (NSERC), and the NASA Atmospheric $\mathrm{CO}_{2}$ Observations from Space (ACOS) program (grant number NNX10AT42G). The GOSAT data were produced by the ACOS/OCO-2 project at the Jet Propulsion Laboratory, California Institute of Technology, and obtained from the ACOS/OCO-2 data archive maintained at the NASA Goddard Earth Science Data and Information Services Center. The Atmospheric Chemistry Experiment (ACE) is a Canadian-led mission mainly supported by the CSA and NSERC. Odin is a Swedish-led satellite project funded jointly by Sweden (SNSB), Canada (CSA), France (CNES), and Finland (Tekes). We thank the two anonymous reviewers for helpful comments on the manuscript.

Edited by: M. K. Dubey

\section{References}

Adams, C., Bourassa, A. E., Bathgate, A. F., McLinden, C. A., Lloyd, N. D., Roth, C. Z., Llewellyn, E. J., Zawodny, J. M., Flittner, D. E., Manney, G. L., Daffer, W. H., and Degenstein, D. A.: Characterization of Odin-OSIRIS ozone profiles with the SAGE II dataset, Atmos. Meas. Tech., 6, 1447-1459, doi:10.5194/amt6-1447-2013, 2013.

Andres, R. J., Gregg, J. S., Losey, L., Marland, G., and Boden, T. A.: Monthly, global emissions of carbon dioxide from fossil fuel consumption, Tellus B, 63, 309-327, doi:10.1111/j.16000889.2011.00530.x, 2011.

Basu, S., Guerlet, S., Butz, A., Houweling, S., Hasekamp, O., Aben, I., Krummel, P., Steele, P., Langenfelds, R., Torn, M., Biraud, S., Stephens, B., Andrews, A., and Worthy, D.: Global $\mathrm{CO}_{2}$ fluxes estimated from GOSAT retrievals of total column $\mathrm{CO}_{2}$, Atmos. Chem. Phys., 13, 8695-8717, doi:10.5194/acp-13-86952013, 2013.

Bernath, P. F., McElroy, C. T., Abrams, M. C., Boone, C. D., Butler, M., Camy-Peyret, C., Carleer, M., Clerbaux, C., Coheur, P. F., Colin, R., DeCola, P., DeMazière, M., Drummond, J. R., Dufour, D., Evans, W. F. J., Fast, H., Fussen, D., Gilbert, K., Jennings, D. E., Llewellyn, E. J., Lowe, R. P., Mahieu, E., McConnell, J. C., McHugh, M., McLeod, S. D., Michaud, R., Midwinter, C., Nassar, R., Nichitiu, F., Nowlan, C., Rinsland, C. P., Rochon, Y. J., Rowlands, N., Semeniuk, K., Simon, P., Skelton, R., Sloan, J. J., Soucy, M. A., Strong, K., Tremblay, P., Turnbull, D., Walker, K. A., Walkty, I., Wardle, D. A., Wehrle, V., Zander, R., and Zou, J.: Atmospheric Chemistry Experiment (ACE): Mission overview, Geophys. Res. Lett., 32, L15S01, doi:10.1029/2005g1022386, 2005.

Boone, C. D., Nassar, R., Walker, K. A., Rochon, Y., McLeod, S. D., Rinsland, C. P., and Bernath, P. F.: Retrievals for the atmospheric chemistry experiment Fourier-transform spectrometer, Appl. Optics, 44, 7218-7231, doi:10.1364/ao.44.007218, 2005.

Bourassa, A. E., McLinden, C. A., Bathgate, A. F., Elash, B. J., and Degenstein, D. A.: Precision estimate for OdinOSIRIS limb scatter retrievals, J. Geophys. Res., 117, D04303, doi:10.1029/2011jd016976, 2012.

Chen, J. M., Liu, J., Cihlar, J., and Goulden, M. L.: Daily canopy photosynthesis model through temporal and spatial scaling for remote sensing applications, Ecol. Model., 124, 99-119, 1999.

Chevallier, F., Palmer, P. I., Feng, L., Boesch, H., O'Dell, C. W., and Bousquet, P.: Toward robust and consistent regional $\mathrm{CO}_{2}$ flux estimates from in situ and spaceborne measurements of atmospheric $\mathrm{CO}_{2}$, Geophys. Res. Lett., 41, 1065-1070, doi:10.1002/2013g1058772, 2014.

Considine, D. B., Logan, J. A., and Olsen, M. A.: Evaluation of near-tropopause ozone distributions in the Global Modeling Initiative combined stratosphere/troposphere model with ozonesonde data, Atmos. Chem. Phys., 8, 2365-2385, doi:10.5194/acp-8-2365-2008, 2008.

Corbett, J. J.: Considering alternative input parameters in an activity-based ship fuel consumption and emissions model: Reply to comment by $\emptyset$. Endresen et al. on "Updated emissions from ocean shipping”, J. Geophys. Res., 109, D23303, doi:10.1029/2004jd005030, 2004.

Corbett, J. J. and Koehler, H. W.: Updated emissions from ocean shipping, J. Geophys. Res., 108, 4650-4666, doi:10.1029/2003jd003751, 2003. 
Degenstein, D. A., Bourassa, A. E., Roth, C. Z., and Llewellyn, E. J.: Limb scatter ozone retrieval from 10 to $60 \mathrm{~km}$ using a multiplicative algebraic reconstruction technique, Atmos. Chem. Phys., 9, 6521-6529, doi:10.5194/acp-9-6521-2009, 2009.

Deng, F. and Chen, J. M.: Recent global $\mathrm{CO}_{2}$ flux inferred from atmospheric $\mathrm{CO}_{2}$ observations and its regional analyses, Biogeosciences, 8, 3263-3281, doi:10.5194/bg-8-3263-2011, 2011.

Deng, F., Chen, J. M., Plummer, S., Chen, M., and Pisek, J.: Algorithm for global leaf area index retrieval using satellite imagery, IEEE T. Geosci. Remote Sens., 44, 2219-2229, doi:10.1109/tgrs.2006.872100, 2006.

Deng, F., Jones, D. B. A., Henze, D. K., Bousserez, N., Bowman, K. W., Fisher, J. B., Nassar, R., O’Dell, C., Wunch, D., Wennberg, P. O., Kort, E. A., Wofsy, S. C., Blumenstock, T., Deutscher, N. M., Griffith, D. W. T., Hase, F., Heikkinen, P., Sherlock, V., Strong, K., Sussmann, R., and Warneke, T.: Inferring regional sources and sinks of atmospheric $\mathrm{CO}_{2}$ from GOSAT $\mathrm{XCO}_{2}$ data, Atmos. Chem. Phys., 14, 3703-3727, doi:10.5194/acp-14-37032014, 2014.

Douglass, A. R., Schoeberl, M. R., Rood, R. B., and Pawson, S.: Evaluation of transport in the lower tropical stratosphere in a global chemistry and transport model, J. Geophys. Res.-Atmos., 108, 4259, doi:10.1029/2002jd002696, 2003.

Endresen, Ø., Sørgård, E., Bakke, J., and Isaksen, I. S. A.: Substantiation of a lower estimate for the bunker inventory: Comment on "Updated emissions from ocean shipping" by James J. Corbett and Horst W. Koehler, J. Geophys. Res., 109, D23302, doi:10.1029/2004jd004853, 2004.

Endresen, Ø., Sørgård, E., Behrens, H. L., Brett, P. O., and Isaksen, I. S. A.: A historical reconstruction of ships' fuel consumption and emissions, J. Geophys. Res., 112, D12301, doi:10.1029/2006jd007630, 2007.

Friedl, R. R.: Atmospheric effects of subsonic aircraft: interim assessment report of the Advanced Subsonic Technology Program, in: National Aeronautics and Space Administration, Goddard Space Flight Center, Greenbelt, MD United States, 168, 1997.

Hegglin, M. I., Boone, C. D., Manney, G. L., Shepherd, T. G., Walker, K. A., Bernath, P. F., Daffer, W. H., Hoor, P., and Schiller, C.: Validation of ACE-FTS satellite data in the upper troposphere/lower stratosphere (UTLS) using non-coincident measurements, Atmos. Chem. Phys., 8, 1483-1499, doi:10.5194/acp8-1483-2008, 2008.

Henze, D. K., Hakami, A., and Seinfeld, J. H.: Development of the adjoint of GEOS-Chem, Atmos. Chem. Phys., 7, 2413-2433, doi:10.5194/acp-7-2413-2007, 2007.

Hoor, P., Fischer, H., Lange, L., Lelieveld, J., and Brunner, D.: Seasonal variations of a mixing layer in the lowermost stratosphere as identified by the $\mathrm{CO}-\mathrm{O}_{3}$ correlation from in situ measurements, J. Geophys. Res.-Atmos., 107, ACL1.1-ACL1.11, doi:10.1029/2000jd000289, 2002.

Houweling, S., Baker, D., Basu, S., Boesch, H., Butz, A., Chevallier, F., Deng, F., Dlugokencky, E. J., Feng, L., Ganshin, A., Hasekamp, O., Jones, D., Maksyutov, S., Marshall, J., Oda, T., O’Dell, C. W., Oshchepkov, S., Palmer, P. I., Peylin, P., Poussi, Z., Reum, F., Takagi, H., Yoshida, Y., and Zhuravlev, R.: An intercomparison of inverse models for estimating sources and sinks of $\mathrm{CO}_{2}$ using GOSAT measurements, J. Geophys. Res.-Atmos., 120, 5253-5266, doi:10.1002/2014jd022962, 2015.
Kalnay, E., Kanamitsu, M., Kistler, R., Collins, W., Deaven, D., Gandin, L., Iredell, M., Saha, S., White, G., Woollen, J., Zhu, Y., Leetmaa, A., Reynolds, R., Chelliah, M., Ebisuzaki, W., Higgins, W., Janowiak, J., Mo, K. C., Ropelewski, C., Wang, J., Jenne, R., and Joseph, D.: The NCEP/NCAR 40-Year Reanalysis Project, Bulletin of the American Meteorological Society, 77, 437-471, doi:10.1175/15200477(1996)077<0437:TNYRP>2.0.CO;2, 1996.

Kim, B. Y., Fleming, G. G., Lee, J. J., Waitz, I. A., Clarke, J.-P., Balasubramanian, S., Malwitz, A., Klima, K., Locke, M., Holsclaw, C. A., Maurice, L. Q., and Gupta, M. L.: System for assessing Aviation's Global Emissions (SAGE), Part 1: Model description and inventory results, Transport. Res. D-Tr. E., 12, 325-346, doi:10.1016/j.trd.2007.03.007, 2007.

Lauvaux, T. and Davis, K. J.: Planetary boundary layer errors in mesoscale inversions of column-integrated $\mathrm{CO}_{2}$ measurements, J. Geophys. Res.-Atmos., 119, 490-508, doi:10.1002/2013jd020175, 2014.

Lin, M., Fiore, A. M., Cooper, O. R., Horowitz, L. W., Langford, A. O., Levy, H., Johnson, B. J., Naik, V., Oltmans, S. J., and Senff, C. J.: Springtime high surface ozone events over the western United States: Quantifying the role of stratospheric intrusions, J. Geophys. Res.-Atmos., 117, D00V22, doi:10.1029/2012jd018151, 2012.

Lin, S.-J. and Rood, R. B.: Multidimensional Flux-Form SemiLagrangian Transport Schemes, Mon. Weather Rev., 124, 20462070, doi:10.1175/1520-0493(1996)124<2046:mffsit>2.0.co;2, 1996.

Llewellyn, E. J., Lloyd, N. D., Degenstein, D. A., Gattinger, R. L., Petelina, S. V., Bourassa, A. E., Wiensz, J. T., Ivanov, E. V., McDade, I. C., Solheim, B. H., McConnell, J. C., Haley, C. S., von Savigny, C., Sioris, C. E., McLinden, C. A., Griffioen, E., Kaminski, J., Evans, W. F., Puckrin, E., Strong, K., Wehrle, V., Hum, R. H., Kendall, D. J., Matsushita, J., Murtagh, D. P., Brohede, S., Stegman, J., Witt, G., Barnes, G., Payne, W. F., Piché, L., Smith, K., Warshaw, G., Deslauniers, D. L., Marchand, P., Richardson, E. H., King, R. A., Wevers, I., McCreath, W., Kyrölä, E., Oikarinen, L., Leppelmeier, G. W., Auvinen, H., Mégie, G., Hauchecorne, A., Lefèvre, F., de La Nöe, J., Ricaud, P., Frisk, U., Sjoberg, F., von Schéele, F., and Nordh, L.: The OSIRIS instrument on the Odin spacecraft, Can. J. Phys., 82, 411-422, doi:10.1139/p04-005, 2004.

MacKenzie, D., Jones, D. B. A., Hegglin, M., Boone, C. D., Walker, K. A., Bernath, P. F., and Murray, L.: Global Structure of the UTLS Mixing Layer and its Link to Regional StratosphereTroposphere Exchange, in preparation, 2015.

Maksyutov, S., Takagi, H., Valsala, V. K., Saito, M., Oda, T., Saeki, T., Belikov, D. A., Saito, R., Ito, A., Yoshida, Y., Morino, I., Uchino, O., Andres, R. J., and Yokota, T.: Regional $\mathrm{CO}_{2}$ flux estimates for 2009-2010 based on GOSAT and groundbased $\mathrm{CO}_{2}$ observations, Atmos. Chem. Phys., 13, 9351-9373, doi:10.5194/acp-13-9351-2013, 2013.

McLinden, C. A., Olsen, S. C., Hannegan, B., Wild, O., Prather, M. J., and Sundet, J.: Stratospheric ozone in 3-D models: A simple chemistry and the cross-tropopause flux, J. Geophys. Res.Atmos., 105, 14653-14665, doi:10.1029/2000jd900124, 2000.

Miyazaki, K., Patra, P. K., Takigawa, M., Iwasaki, T., and Nakazawa, T.: Global-scale transport of carbon diox- 
ide in the troposphere, J. Geophys. Res., 113, D15301, doi:10.1029/2007jd009557, 2008.

Nassar, R., Jones, D. B. A., Suntharalingam, P., Chen, J. M., Andres, R. J., Wecht, K. J., Yantosca, R. M., Kulawik, S. S., Bowman, K. W., Worden, J. R., Machida, T., and Matsueda, H.: Modeling global atmospheric $\mathrm{CO}_{2}$ with improved emission inventories and $\mathrm{CO}_{2}$ production from the oxidation of other carbon species, Geosci. Model Dev., 3, 689-716, doi:10.5194/gmd-3-689-2010, 2010.

O’Dell, C. W., Connor, B., Bösch, H., O’Brien, D., Frankenberg, C., Castano, R., Christi, M., Eldering, D., Fisher, B., Gunson, M., McDuffie, J., Miller, C. E., Natraj, V., Oyafuso, F., Polonsky, I., Smyth, M., Taylor, T., Toon, G. C., Wennberg, P. O., and Wunch, D.: The $\mathrm{ACOS} \mathrm{CO}_{2}$ retrieval algorithm - Part 1: Description and validation against synthetic observations, Atmos. Meas. Tech., 5, 99-121, doi:10.5194/amt-5-99-2012, 2012.

Pan, L. L., Randel, W. J., Gary, B. L., Mahoney, M. J., and Hintsa, E. J.: Definitions and sharpness of the extratropical tropopause: A trace gas perspective, J. Geophys. Res.-Atmos., 109, D23103, doi:10.1029/2004jd004982, 2004.

Parazoo, N. C., Denning, A. S., Kawa, S. R., Pawson, S., and Lokupitiya, R.: $\mathrm{CO}_{2}$ flux estimation errors associated with moist atmospheric processes, Atmos. Chem. Phys., 12, 6405-6416, doi:10.5194/acp-12-6405-2012, 2012.

Plumb, R. A. and Ko, M. K. W.: Interrelationships between mixing ratios of long-lived stratospheric constituents, J. Geophys. Res.Atmos., 97, 10145-10156, doi:10.1029/92jd00450, 1992.

Postel, G. A. and Hitchman, M. H.: A Climatology of Rossby Wave Breaking along the Subtropical Tropopause, J. Atmos. Sci., 56, 359-373, doi:10.1175/15200469(1999)056<0359:acorwb>2.0.co;2, 1999.

Prather, M. J.: Numerical advection by conservation of secondorder moments, J. Geophys. Res.-Atmos., 91, 6671-6681, doi:10.1029/JD091iD06p06671, 1986.

Prather, M. J., Zhu, X., Strahan, S. E., Steenrod, S. D., and Rodriguez, J. M.: Quantifying errors in trace species transport modeling, P. Natl. Acad. Sci. USA, 105, 19617-19621, doi:10.1073/pnas.0806541106, 2008.

Reuter, M., Buchwitz, M., Hilker, M., Heymann, J., Schneising, O., Pillai, D., Bovensmann, H., Burrows, J. P., Bösch, H., Parker, R., Butz, A., Hasekamp, O., O'Dell, C. W., Yoshida, Y., Gerbig, C., Nehrkorn, T., Deutscher, N. M., Warneke, T., Notholt, J., Hase, F., Kivi, R., Sussmann, R., Machida, T., Matsueda, H., and Sawa, Y.: Satellite-inferred European carbon sink larger than expected, Atmos. Chem. Phys., 14, 13739-13753, doi:10.5194/acp-1413739-2014, 2014.

Sankey, D. and Shepherd, T. G.: Correlations of long-lived chemical species in a middle atmosphere general circulation model, J. Geophys. Res.-Atmos., 108, 4494, doi:10.1029/2002jd002799, 2003.

Shuckburgh, E., d'Ovidio, F., and Legras, B.: Local Mixing Events in the Upper Troposphere and Lower Stratosphere. Part II: Seasonal and Interannual Variability, J. Atmos. Sci., 66, 3695-3706, doi:10.1175/2009jas2983.1, 2009.

Singh, K., Sandu, A., Bowman, K. W., Parrington, M., Jones, D. B. A., and Lee, M.: Ozone data assimilation with GEOS-Chem: a comparison between 3-D-Var, 4-D-Var, and suboptimal Kalman filter approaches, Atmos. Chem. Phys. Discuss., 11, 2224722300, doi:10.5194/acpd-11-22247-2011, 2011.
Sioris, C. E., Boone, C. D., Nassar, R., Sutton, K. J., Gordon, I. E., Walker, K. A., and Bernath, P. F.: Retrieval of carbon dioxide vertical profiles from solar occultation observations and associated error budgets for ACE-FTS and CASS-FTS, Atmos. Meas. Tech., 7, 2243-2262, doi:10.5194/amt-7-2243-2014, 2014.

Stephens, B. B., Gurney, K. R., Tans, P. P., Sweeney, C., Peters, W., Bruhwiler, L., Ciais, P., Ramonet, M., Bousquet, P., Nakazawa, T., Aoki, S., Machida, T., Inoue, G., Vinnichenko, N., Lloyd, J., Jordan, A., Heimann, M., Shibistova, O., Langenfelds, R. L., Steele, L. P., Francey, R. J., and Denning, A. S.: Weak Northern and Strong Tropical Land Carbon Uptake from Vertical Profiles of Atmospheric $\mathrm{CO}_{2}$, Science, 316, 1732-1735, doi:10.1126/science.1137004, 2007.

Stevenson, D. S., Dentener, F. J., Schultz, M. G., Ellingsen, K., van Noije, T. P. C., Wild, O., Zeng, G., Amann, M., Atherton, C. S., Bell, N., Bergmann, D. J., Bey, I., Butler, T., Cofala, J., Collins, W. J., Derwent, R. G., Doherty, R. M., Drevet, J., Eskes, H. J., Fiore, A. M., Gauss, M., Hauglustaine, D. A., Horowitz, L. W., Isaksen, I. S. A., Krol, M. C., Lamarque, J. F., Lawrence, M. G., Montanaro, V., Müller, J. F., Pitari, G., Prather, M. J., Pyle, J. A., Rast, S., Rodriguez, J. M., Sanderson, M. G., Savage, N. H., Shindell, D. T., Strahan, S. E., Sudo, K., and Szopa, S.: Multimodel ensemble simulations of present-day and near-future tropospheric ozone, J. Geophys. Res.-Atmos., 111, D08301, doi:10.1029/2005jd006338, 2006.

Strahan, S. E. and Polansky, B. C.: Meteorological implementation issues in chemistry and transport models, Atmos. Chem. Phys., 6, 2895-2910, doi:10.5194/acp-6-2895-2006, 2006.

Takahashi, T., Sutherland, S. C., Wanninkhof, R., Sweeney, C., Feely, R. A., Chipman, D. W., Hales, B., Friederich, G., Chavez, F., Sabine, C., Watson, A., Bakker, D. C. E., Schuster, U., Metzl, N., Yoshikawa-Inoue, H., Ishii, M., Midorikawa, T., Nojiri, Y., Körtzinger, A., Steinhoff, T., Hoppema, M., Olafsson, J., Arnarson, T. S., Tilbrook, B., Johannessen, T., Olsen, A., Bellerby, R., Wong, C. S., Delille, B., Bates, N. R., and de Baar, H. J. W.: Climatological mean and decadal change in surface ocean $\mathrm{pCO}_{2}$, and net sea-air $\mathrm{CO}_{2}$ flux over the global oceans, Deep-Sea Res. Pt. II, 56, 554-577, 2009.

van der Werf, G. R., Randerson, J. T., Giglio, L., Collatz, G. J., Mu, M., Kasibhatla, P. S., Morton, D. C., DeFries, R. S., Jin, Y., and van Leeuwen, T. T.: Global fire emissions and the contribution of deforestation, savanna, forest, agricultural, and peat fires (19972009), Atmos. Chem. Phys., 10, 11707-11735, doi:10.5194/acp10-11707-2010, 2010.

Wang, Y., Jacob, D. J., and Logan, J. A.: Global simulation of tropospheric $\mathrm{O}_{3}-\mathrm{NO}_{x}$-hydrocarbon chemistry: 3. Origin of tropospheric ozone and effects of nonmethane hydrocarbons, J. Geophys. Res.-Atmos., 103, 10757-10767, doi:10.1029/98jd00156, 1998.

Waugh, D. W., Plumb, R. A., Elkins, J. W., Fahey, D. W., Boering, K. A., Dutton, G. S., Volk, C. M., Keim, E., Gao, R. S., Daube, B. C., Wofsy, S. C., Loewenstein, M., Podolske, J. R., Chan, K. R., Proffitt, M. H., Kelly, K. K., Newman, P. A., and Lait, L. R.: Mixing of polar vortex air into middle latitudes as revealed by tracer-tracer scatterplots, J. Geophys. Res.-Atmos., 102, 1311913134, doi:10.1029/96jd03715, 1997.

Wilkerson, J. T., Jacobson, M. Z., Malwitz, A., Balasubramanian, S., Wayson, R., Fleming, G., Naiman, A. D., and Lele, S. K.: Analysis of emission data from global commercial avi- 
ation: 2004 and 2006, Atmos. Chem. Phys., 10, 6391-6408, doi:10.5194/acp-10-6391-2010, 2010.

Wofsy, S. C., Team, H. S., Cooperating, M., and Satellite, T.: HIAPER Pole-to-Pole Observations (HIPPO): fine-grained, global-scale measurements of climatically important atmospheric gases and aerosols, Philos. T. R. Soc. A, 369, 2073-2086, doi:10.1098/rsta.2010.0313, 2011.

Wofsy, S. C., Daube, B. C., Jimenez, R., Kort, E., Pittman, J. V., Park, S., Commane, R., Xiang, B., Santoni, G., Jacob, D., Fisher, J., Pickett-Heaps, C., Wang, H., Wecht, K., Wang, Q.-Q., Stephens, B. B., Shertz, S., Watt, A. S., Romashkin, P., Campos, T., Haggerty, J., Cooper, W. A., Rogers, D., Beaton, S., Hendershot, R., Elkins, J. W., Fahey, D. W., Gao, R. S., Moore, F., Montzka, S. A., Schwarz, J. P., Perring, A. E., Hurst, D., Miller, B. R., Sweeney, C., Oltmans, S., Nance, D., Hintsa, E., Dutton, G., Watts, L. A., Spackman, J. R., Rosenlof, K. H., Ray, E. A., Hall, B., Zondlo, M. A., Diao, M., Keeling, R., Bent, J., Atlas, E. L., Lueb, R., and Mahoney, M. J.: HIPPO Merged 10-second Meteorology, Atmospheric Chemistry, Aerosol Data (R_20121129). Carbon Dioxide Information Analysis Center, Oak Ridge National Laboratory, Oak Ridge, Tennessee, USA, doi:10.3334/CDIAC/hippo_010, 2012.
Xiong, X., Barnet, C., Maddy, E., Wofsy, S. C., Chen, L., Karion, A., and Sweeney, C.: Detection of methane depletion associated with stratospheric intrusion by atmospheric infrared sounder (AIRS), Geophys. Res. Lett., 40, 2455-2459, doi:10.1002/grl.50476, 2013.

Yevich, R. and Logan, J. A.: An assessment of biofuel use and burning of agricultural waste in the developing world, Global Biogeochem. Cy., 17, 1095-1134, doi:10.1029/2002gb001952, 2003.

Zhang, L., Jacob, D. J., Downey, N. V., Wood, D. A., Blewitt, D., Carouge, C. C., van Donkelaar, A., Jones, D. B. A., Murray, L. T., and Wang, Y.: Improved estimate of the policy-relevant background ozone in the United States using the GEOS-Chem global model with $1 / 2^{\circ} \times 2 / 3^{\circ}$ horizontal resolution over North America, Atmos. Environ., 45, 6769-6776, doi:10.1016/j.atmosenv.2011.07.054, 2011. 